\title{
TRANSNATIONAL GOVERNANCE AND ITS IMPACT ON THE SETTLEMENT PROCESS OF ERITREAN REFUGEES IN CANADA
}

\author{
BY \\ Aaron Berhane, BA, University of Asmara, 2000 \\ A Major Research Paper \\ Presented to Ryerson University \\ in partial fulfillment of the requirements for the degree of \\ Master of Arts \\ in the Program of \\ Immigration and Settlement Studies
}

Toronto, Ontario, Canada, 2016

(C) Aaron Berhane 2016 


\section{AUTHOR'S DECLARATION FOR ELECTRONIC SUBMISSION OF A MAJOR RESEARCH PAPER (MRP)}

I hereby declare that I am the sole author of this Major Research Paper. This is a true copy of the MRP, including any required final revision, as accepted by my examiner.

I authorize Ryerson University to lend this MRP to other institutions or individuals for the purpose of scholarly research.

I further authorize Ryerson University to reproduce this MRP by photocopying or by other means, in total or in part, at the request of other institutions or individuals for the purpose of scholarly research.

I understand that my MRP may be made electronically available to the public.

Aaron Berhane 


\title{
TRANSNATIONAL GOVERNANCE AND ITS IMPACT ON THE SETTLEMENT PROCESS OF ERITREAN REFUGEES IN CANADA
}

\author{
Aaron Berhane \\ Masters of Arts 2016 \\ Immigration and Settlement Studies \\ Ryerson University
}

\begin{abstract}
This paper will examine the transnational governance and its impact on the settlement process of Eritrean refugees. It will pose three questions: 1) What kind of challenges do Eritrean refugees face in the process of their resettlement? 2) How do the illegal activities of the Eritrean consulate disrupt their settlement process? 3) What difficulties do newcomers have in accessing law enforcement authorities? The paper will focus on the cases of Eritrean immigrants in Canada and investigate how the state of their country of origin continues to affect their day to day life in the country of reception and particularly how the home state regulates the flow of money and works to silence its critics. The paper further will investigate how the activities of Eritrean government can undermine Canadian sovereignty and leave refugees defenseless. Although the analysis is based on the experiences of Eritrea and its refugees in Canada, the paper will argue that such transnational governance can emasculate the autonomy of any country that hosts refugees or immigrants.
\end{abstract}

\section{Key words:}

Coercive transnational governance, Eritrean Consulate, 2 \% income tax, settlement challenges, Eritrean refugees 


\section{ACKNOWLEDGEMENT}

I would like to express my heartfelt gratitude to my supervisor, Dr. Idil Atak, who has guided me throughout the completion of this MRP by providing prompt and critical feedbacks. My gratitude also goes to my second reader, Dr. Myer Siemiatycki, who always goes extra mile to assist students and provide a thoughtful and engaging insights. The knowledge and expertise of both my supervisor and second reader contributed to my final achievement.

I am also grateful to 11 individuals who took their time out of their busy and hectic schedule to share their experiences with me. This paper would not have been possible without their cooperation.

I would like to thank my wife and children for their patience and for always giving me encouragement, love and support. 


\section{DEDICATIONS}

I dedicate this work to my family for believing in me, for their encouragement, support and concern. 


\section{TABLE OF CONTENTS}

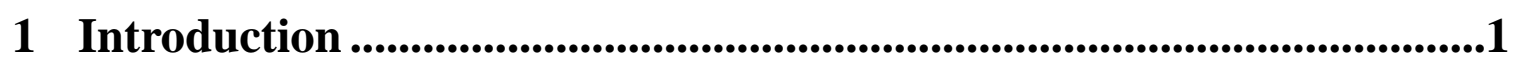

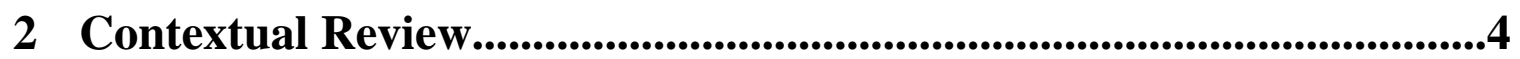

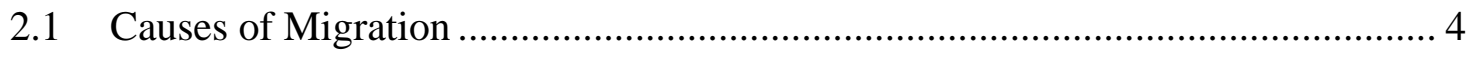

2.2 Contemporary Situation \& the Government Control Mechanism ...................... 6

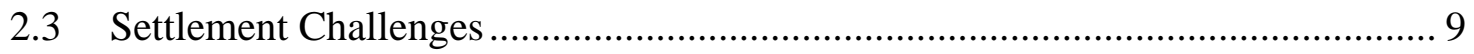

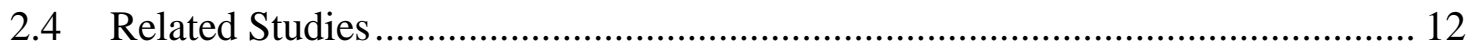

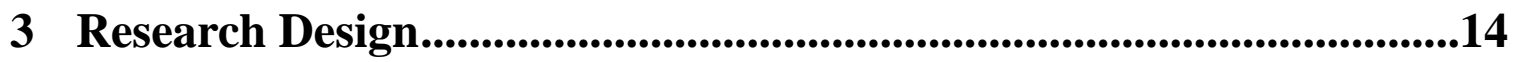

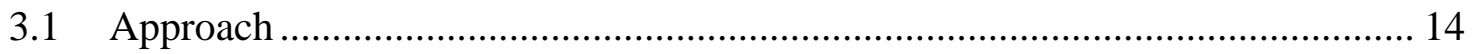

3.2 Philosophical / Theoretical Approach ........................................................ 15

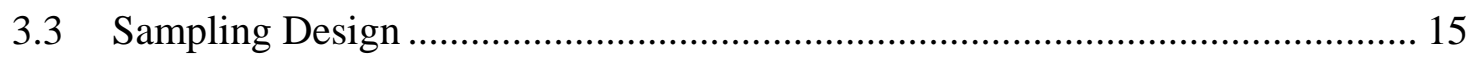

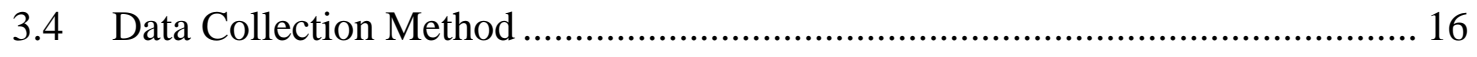

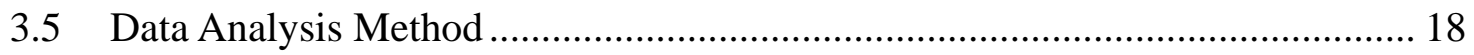

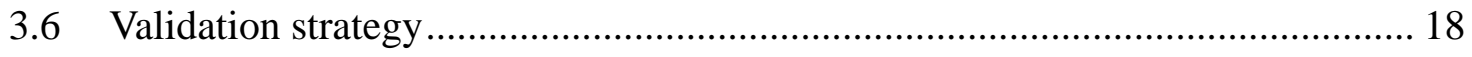

4 Research Findings ..............................................................................................20

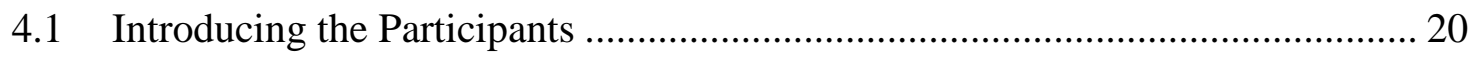

4.2 The Fear That Shadows Eritrean Refugees ….............................................. 26

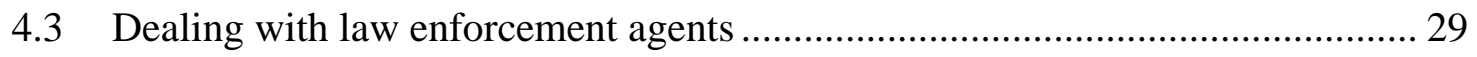




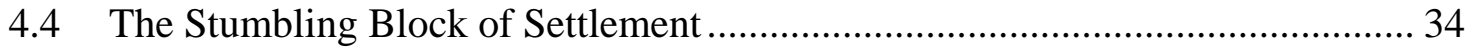

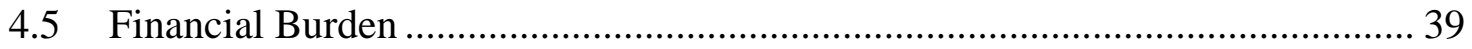

4.6 My Personal Settlement Experience ................................................................ 45

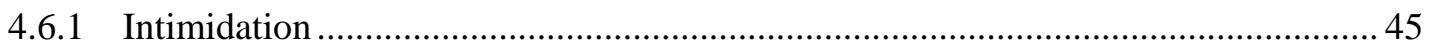

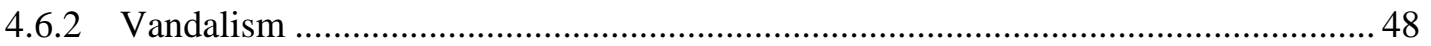

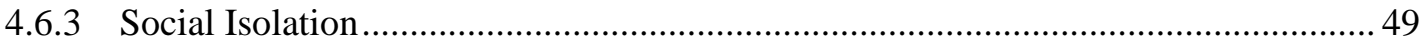

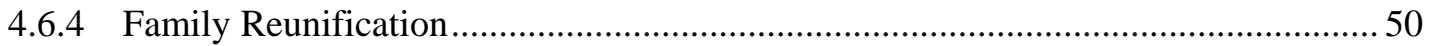

5 Conclusion and Recommendations...........................................................52

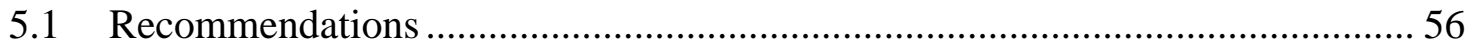

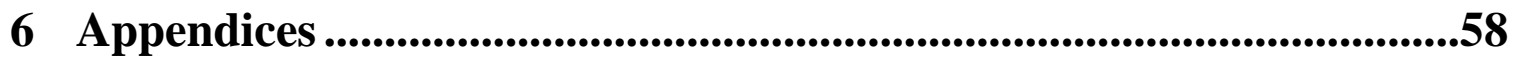

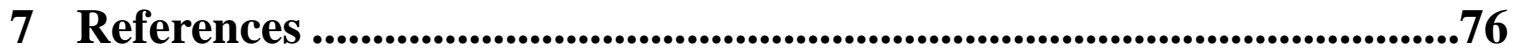




\section{Introduction}

Canada has been a safe haven for thousands of refugees who fled the dictatorial regimes of their home countries. Those refugees escape persecution or simply immigrate to enjoy the peaceful lifestyle, have played their role in developing their hosting country. They have become part of the social, political and economic fabrics of the society. They have taken advantage of the political stability of the country to educate their children, run businesses and pursue their education. Canada also depends on them to increase its population and labour market. There is a mutual interest on both sides. Therefore, it is important for Canada to create a secure system to protect refugees and ensure that their integration process moves smoothly, and that they overcome their challenges victoriously; because refugees are more vulnerable to coercive transnational governance and organized crime.

Though language barriers, lack of employment, lack of recognition of international credentials are the most discussed obstacles of refugees' integration achievements, the security challenges refugees face haven't received the attention they deserve. Intimidation, threat and surveillance on the refugees' life are some of them. These put the peace and mental stability of some refugees at risk and delays their integration process. The case of Eritrean immigrants is a good example.

For decades, Eritreans have been dispersed from their home country as a result of colonial aggression from 1890 to 1991, and the struggle against Ethiopia from 1961 to 1991, which contributed to the emigration of more than half a million people (Hepner, 2008). Their resettlement in Canada started in the early 1980s (Tezare et al., 2006) and continued to grow even after Eritrea became independent. They, like many African immigrants, have experienced a number of challenges in Canada during their settlement process. Discrimination in accessing employment, 
finding a place to live, and mastering the official languages (Tezare et al., 2006). However, their settlement experience was very unique because their challenges didn't come only from the host society but also from the government of their home country.

The Eritrean regime has stretched its hand to seize donations, collect illegal taxes, force Eritrean immigrants to attend fundraising meetings and tries to silence them whenever they voice their criticism against the government. The state's involvement in all facets of their life aggravates clashes in exile or in their home country (Hepner, 2008). "The impacts of Eritrean nationalism on transnationalism, and vice versa, remain salient" (Hepner, 2008: 477) even after they have lived in exile for decades.

The Eritrean state uses its transnational institutions not to cultivate the participation of the people's socio-political activities or to enable their influence in the foreign world, but to restrict their activities, control their influence and make them obedient to the regime (al-Ali, Black and Koser 2001a, 2001b; Hepner 2003; Conrad and Hepner 2005; Hepner, 2008).

The sum of such challenges has exacerbated the settlement struggle of Eritrean-Canadian for more than a decade. There are about 30,000 Eritreans live in Canada and majority of them in Ontario. This paper will investigate the coercive transnational governance (CTG) and its impact on the settlement process of immigrants. CTG is a form of governance that dictatorial regimes use to maintain political control and secure financial contribution by force from their citizens who settled in Western World as refugees. This study will pose three questions:

1) What kind of challenges do Eritrean refugees face in the process of their settlement?

2) How do the illegal activities of the Eritrean consulate disrupt their settlement process? 
3) What difficulties do newcomers have in accessing law enforcement authorities?

The paper will examine how the state of their country of origin which is located thousands of miles away, continues to affect their day-to-day life in Canada and particularly how the home state regulates the flow of private funds and activities of its citizens abroad, and works to silence its critics. The paper will further investigate how the activities of the Eritrean government can undermine Canadian law and leave refugees defenceless. Although the analysis is based on the experiences of Eritrea and its refugees in Canada, the paper will argue that such transnational governance can emasculate the autonomy of any country that hosts refugees or immigrants. 


\section{Contextual Review}

The contextual review includes causes of Eritrean migration, contemporary situation of the Eritrean government, and related studies with regard to settlement challenges. This will give us adequate understanding about the causes of Eritrean migration and colonial legacies; the policies and activities of the Eritrean government and nature of its administration; and other relevant studies that can expand our knowledge of transnational governance.

\subsection{Causes of Migration}

Eritrea had been a colony of Italy, British and Ethiopia for about 100 years (1890-1991). During that period, the people experienced harsh treatment. The colonialists were intolerant and punished anyone who tried to challenge their rule (Kibreab, 2007). Many people fled the country to save their lives. As a result, about one-fourth of Eritrea's six million people still live in exile. Even after Eritrea's independence in 1991, the number of people who fled the country increased due to gross human rights violations, forced labor, brutal administration, and a system of "ruthless repression “and “pervasive state control” (UN Commission of Inquiry on Human Rights In Eritrea, 2015).

The Eritrean diaspora's transnational activities are grounded in the social realities of relations that they have with their home country, family members as well as the diaspora community. Though it is necessary to note that the diaspora community formed before the emergence of Eritrea's nationalist movement of the 1940s and 1950s, the current transnational community is connected to the struggle against colonialism and war for independence (Kibreab, 2007, 98). During the 30year revolutionary struggle of the Eritrean People’s Liberation Front (EPLF) from 1961-1991, about one million people escaped and ended up in refugee camps or were restricted from returning home (Hepner, 2003). About 700,000 of these expatriates went to Ethiopia, Kenya, Egypt, North 
America, Europe, Australia, or the Middle East, with the remaining 300,000 who migrated to Sudan (Hepner, 2003). The Eritrean diaspora in Canada 'started to immigrate to Canada in the late 1970s to early 1980s' (Tezare et al, 2006). Eritrean refugees, wherever they settled, were organized and mobilized by EPLF to play their part in the ongoing struggle of independence of their country. During all those years, the EPLF spread itself as a social and political organization among Eritreans abroad, and organized the Diasporas into chapters of the EPLF and its mass associations to channel and manage their support in the revolution (Hepner 2004, 2005, 2008).

Nonetheless, the migration slowed down after Eritrea became independent in 1991, but the region was not able to enjoy the peace it deserved. The eruption of border conflicts with Ethiopia from 1998-2000 and the political instability throughout the country forced many citizens to flee. According to the 2013 report of UNHCR, about 4000 Eritrean flee the country every month to escape ruthless repression, persecution and forced labour.

Currently, Eritrea is one of the leading refugee-producing countries around the world (Human Rights Watch, 2009; UNHCR, 2014). This constant flow has increased the number of Eritrean Diaspora rapidly all over the world. There are no accurate data about the size of the Eritrean populations in host countries in North America and Europe (Tezare et al, 2006). As Al-Ali et al (2001) perceived, this is essentially because of the way that they (Eritrean) were registered upon landing as "Ethiopians" as opposed to "Eritreans" (Al-Ali et al, 2001), because most of them came before Eritrea's independence of 1991. However, according to the estimation of community leaders, there are about 30,000 Eritrean live in Canada and majority of them in Ontario. 


\subsection{Contemporary Situation \& the Government Control Mechanism}

After Eritrea became independent in 1991, government officials secured financial and political support from Eritrean refugees via embassies and consulates which they had created in Europe and North America and the constant visits they made to the major settlement cities of Eritrean diasporas (Newland and Patrick, 2004; Poole, 2013). The government 'institutionalized the practice of remittance-giving to the national cause through the 2\% Income Tax on Eritreans Working Abroad' (Tecle, 2012: 25). The diaspora who used to give voluntarily during Eritrea's war for independence were forced to give involuntarily. They are required to pay $2 \%$ of their annual income as 'set out into law under Proclamation No 17/1991 \& 67/1995 and described as a "Rehabilitation and Recovery Tax” (Mehwey Gibri)’ (Independent Advisory Group on Country Information, 2015 September).

The practice of collecting tax from expatriate citizens may not be new in the contemporary world, but the way Eritrean government practices its 'tax collection' is unique. "The 2\% tax neither operates as an income tax nor is it governed by bilateral tax treaties” (Tecle, 2012: 24). Moreover, despite the underlying proclamation, Eritrea's Ministry of Foreign Affairs described the collection of the $2 \%$ income tax as 'voluntary, legal and legitimate' and sometimes referred to it as 'property tax’ (Ministry of Foreign Affairs of The State of Eritrea, 2011 October 17). However, unlike the claims of the Eritrean government, the 2\% income tax levied on people of Eritrean descent is not voluntary. Neither does it follow the rules of property tax or proper taxation. The representatives of the Eritrean government use coercive methods to collect the 2\% income tax from the diaspora (UN Monitoring Group, 2012: 53). This taxation is not property tax either as the representatives 
of the regime demand payment from Eritreans who own no property in Eritrea (Gedab News, 2011 July 29).

Moreover, the diaspora tax provision does not function like a legitimate taxation of an income (Tecle, 2012; Weldehaimanot, 2011). The Eritrean government uses it as a means to collect funds by collaborating with the consular services. 'Payment of the tax is a prerequisite for obtaining any government service from Eritrean consular or embassy officials’ (UN Monitoring Group, 2015: 26).

If one examines the ' $2 \%$ Income Tax form' closely, one tends to discover that the practice is more than just taxing foreign nationals of Eritrean descent on their annual income tax. The tax collectors request the payers to bring proof of their income (usually their income tax returns, or in the case of students, proof of enrollment at school). As Appendix 2 shows, the $2 \%$ income tax form includes separate columns for retrospective mandatory contribution for the three phases (Ethiopian invasion) of the Ethio-Eritrean border conflict (1998-2000) and mandatory donations (Wefeya) for the Eritrean Defence Forces which is normally said to be $\$ 500$ per family. “. . .the Government and PFDJ collect and control hundreds of millions of dollars each year in unofficial revenues, largely from taxation of Eritreans in the diaspora” and other sources (UN Monitoring Group, 2011: 97). This could be one of the main source of income for Eritrea which is ranked 182 from 187 countries in the 2013 Human Development Index. According to World Bank, Eritrea's national income per capita is $\$ 680$ and its Gross Domestic Product is $\$ 3.86$ billion in 2014 . The 30-35\% of that GDP is believed to be collected from the $2 \%$ income taxes and other remittances (Fessehatzion 2005; Tecle 2012) 
Realizing the poor situation of the country, paying the $2 \%$ tax was not an issue in the beginning for most of the Eritrean diaspora. They considered it part of their duty-a contribution to the rehabilitation of the damaged economy. But that didn't last long. When they saw that the government was becoming an authoritarian regime running the country without accountability, they started to withdraw their political and financial support. They questioned the practice of collecting the $2 \%$ income tax, considering it coercive and contrary to the rule of law. But still for many members of the diaspora, it was not easy to release themselves from the control of the regime and leave of their own free will. They felt trapped.

Eritrea is an African version of North Korea (Bengali, 2009). The regime suppresses basic human rights and liberties of the people by converting the country into an open prison. 'No political opposition parties, independent media, civil society organizations or unregistered faith groups were permitted to operate' (Amnesty International, 2014). Nor were they allowed freedom of movement (travel).

The Eritrean government also attempts to control its transnational community by creating a tight network all over the world.

As Hepner (2008) noted, the Eritrean state controls the life of people who live inside or outside the country by installing undercover representatives in every community event, gathering or association. ". . . the state materializes seemingly everywhere at once, appearing in the guise of development projects and national service policies, state-approved non-governmental 
organizations, handpicked religious leaders, holiday parties and fundraisers abroad, and party members who record the activities of compatriots" (Hepner, 2008: 477).

The invasive involvement of the Eritrean government in their diaspora life rocks their settlement and integration experiences very hard in the host countries. Instead of focusing on recovering from the traumatic experience of war, escape and loss of their loved ones, Eritreans are reminded to live in a 'climate of fear' (Popkin 2003, p. 369).

The purpose of the regime in expanding its networks and institutionalizing its transnational governance is to strengthen and tighten its control 'over the political, economic and cultural spheres.' However, it has created a crack inside and outside Eritrea due to the destruction of the 'social and political institutions' in the community (Tronvoll, 1998; Connell, 2005; Hepner, 2008). Nevertheless, it has built a functional secure system that can undermine Canadian law and rule the Eritrean community wherever they are.

\subsection{Settlement Challenges}

Some authoritarian countries, usually with high emigration, apply a diverse range of mechanisms to engage their diasporas for financial extraction (Itzigsohn 2000; Goldring 2003; Levitt and de la Dehesa 2003). The practice of the Eritrean government in engaging its diaspora community for its own means has so many layers of concern. It affects the refugees' settlement process negatively.

The Eritrean consulate in Canada uses extortion, threats of violence and other illegal means to collect 2\% taxes, donations and organize fundraising events (UN Monitoring Group, 2012). The assessment of the Royal Canadian Mounted Police (RCMP) that was included in the report of the UN Monitoring Group states the issue as follows: a "refusal to pay the tax often results in denial 
of service or threats against, or harassment of, family members still residing in Eritrea, or possible arrest of the individual should they travel to Eritrea without paying the taxes alleged to be owing” (UN Monitoring Group, 2012).

For instance, in order to fulfill the Citizenship and Immigration Canada (CIC) requirement, Wegahta Tesfamariam had to contact the Eritrean Consulate to renew her Eritrean passport, but 'her home country demanded a share of her annual income in a levy which some liken to extortion' (MacInnes-Rae, 2014). Of course, Ms. Tesfamariam was appalled and she refused to pay, but that would throw her in a stateless limbo with 'her passport about to expire, and no prospect of getting a new one’ (MacInnes-Rae, 2014).

Eritrean refugees also go through a hard time in sponsoring their family members from their home country because of the obstacles the Eritrean Consulate creates. Scallan (2012) interviewed an Eritrean refugee who didn't want to be named out of fear of vengeance. He described the first trouble the refugee faced from the Eritrean consulate. He fled Eritrea in 2001 and he visited the Eritrean consulate in Toronto three years later to request an exit visa for his wife and child who were denied exit visas from Eritrea because he didn’t pay the 2\% income tax. 'The consulate demanded that he pays the $2 \%$ income tax for every year since he arrived in 2001 in order to receive the help he needed to reunite with his family' (Scallan, 2012). Despite his situation (he was living on social welfare at the time), the refugee was asked 'to pay $\$ 5$ from every monthly welfare cheque', and he didn't have any choice but to fulfil the consulate's request (Scallan, 2012).

Some Eritrean refugees want to pursue their education once they resettle in Canada. But getting their educational documents from their home country is a painful process. Bell (2012) interviewed Eritrean refugees who faced challenges in securing documents from Eritrea. A refugee who lives 
in Winnipeg but doesn't want to be named for the sake of his family's safety was '...eager to continue his studies in Canada'. He therefore requested that his document be sent to him but was told that he would get it if he paid the $2 \%$ diaspora tax (Bell, 2012). He was making very little money and 'the tax was in the hundreds of dollars.' But what disturbed him more was to have to pay the government that had forced him into exile (Bell, 2012).

According to UNSC-1907 which was incorporated into Canadian law in April 2010, it is prohibited for any person in Canada to knowingly 'provide or transfer, directly or indirectly, technical or financial assistance related to military activities’ (Canada Gazette, 2010).

Therefore, the 2\% Diaspora tax, through its inclusion of mandatory payments or contributions for the Eritrean defense forces violates the UN resolution which also became part of the domestic law in Canada. That can put Eritrean refugees at risk as they are forced to violate Canadian law so as to fulfill the requirement of the Eritrean Consulate.

The Human Rights activists have complained about the illegal activities of the Eritrean consulate for a number of years. Finally, in May 2013, the Consulate General of Eritrea was expelled after he ignored Canada's warning to stop soliciting money from the Eritrean diaspora for military and other purposes (Bell, 2013).

The authoritarian regime of Eritrea instills a 'climate of fear' among the Eritrean diaspora to 'paralyze migrant communities’ (Popkin 2003, p. 369). Political institutions of the regime such as the Women's Association, and the Youth PFDJ are involved in leading and implementing the ruling party's agendas to the functioning of this ‘despotic modality of governance’ (Bozzini 2011). The role of such associations in spying community members, organizing festivals and raising fund 
is crucial. "Social, cultural and political fund-raising events, including — since late 2009 — rallies against the imposition of United Nations sanctions, are regularly organized in Australia, Canada, Denmark, France, Germany, Italy, the Netherlands, Norway, Sweden, Switzerland, the United Kingdom and the United States by Eritrean embassy officials and affiliated individuals" (UN Monitoring Group, 2011: 102).

\subsection{Related Studies}

Political process can be swayed by the transnational communities as well as by the countries sending the refugees and most of the time the diaspora can be instrumental in mobilizing supporters and raising funds (Lyons and Mandaville, 2012). The opposition parties of an authoritarian regime assign representatives from the diaspora community so as to expand their influence. Their undemocratic behaviour may spill over in the diaspora community (Lyons and Mandaville, 2012) as a result of the nature of their politics. Such a situation could expose the diaspora community at risk. Refugees are described as people who need protection by the institution, legislation and sets of norms that consists of transnational layers (Koser, 2007: 248). The hosting states need to be aware of the type of control or pressure a sending country imposes on the diaspora community.

There is very little literature available related to the experience of the Eritrean diaspora. The TamilCanadians' experience may have some resemblance to the Eritrean diaspora, though the extortion is not done by the government of Sri Lanka but by the Liberation Tigers Tamil Eelam (LTTE). La (2004) describes how the transnational ties of Tamil refugees who reside in Canada are exploited by the LTTE. The LTTE has persecuted Tamils in the countries where they have been granted asylum. 
The developing countries that force their citizens to end up in exile can target or extort them as soon as the refugees are granted asylum in the developed states and improve their economic status in their new home (La, 2004). La (2004) further articulates the 'strong social networks among the Tamil diaspora, coupled with the relative openness of Canadian civil society, have made Tamil refugees vulnerable to LTTE exploitation by reinforcing transnational ties that are highly prone to manipulation’ ( La, 2004).

The activities of LTTE have a chance to flourish in the refugee enclaves centers, and its exposed refugees are vulnerable to coercion and intimidation (La, 2004). 


\section{Research Design}

\subsection{Approach}

In this research paper, a qualitative approach is used to tackle the main research questions. This approach can give the researcher an opportunity to ask follow-up questions based on the response of the participants. It also allows to record the unique and in-depth experience of the individuals on the issue in the study as such information is impossible to extract from the pool of numerical data.

Moreover, the research employs a qualitative case study as a methodology to explore the core issues of the problem. Case studies are useful when exploring social problems like the one this study is tackling and when collecting data in real time (Yin, 2009). Stake (1995) articulates its importance in comprehending the unique problems or threat of a specific group. Since very little literature exists on the challenges of Eritrean refugees in Canada, and many of them do not share openly out of fear, a one-to-one interview with those refugees is extremely crucial to capture the essence of their lives experience in Canada.

The information gathered from this study can be used to advance knowledge of the resettlement challenges of Eritrean refugees and the impact of the coercive transnational governance in their integration process in Canada. However, this finding cannot be generalized to all Eritrean immigrants in Canada. 


\subsection{Philosophical / Theoretical Approach}

The theoretical approach that the researcher uses in studying the resettlement challenges of Eritrean refugees is coercive transnational governance (CTG). Coercive transnational governance is a form of governance that dictatorial regimes use to maintain political control and secure financial contribution by force from their citizens who settled in Western World as refugees. The purpose of CTG is to explore the hidden cross country administration of immigrants sending countries. The sending countries try to exploit the wealth and resources of their transnational citizens by using force or providing incentives. It is a preferable approach to navigate the transnational governance if it jeopardizes the safety and security of immigrants or refugees.

The study is approached with a qualitative case study. Its purpose is to explore social problem in depth ways echoed by ‘silenced voices’ (Creswell, 2013, 48). Case study in qualitative research can go beyond literature reviews to understand the complex issues of the problem by talking to subjects face to face, going to where they live and empowering them to tell their own stories (Creswell, 2013). Therefore, using a case study approach allows the researcher to hear directly the challenges Eritrean refugees face during their resettlement process. This method has been effective in examining and gathering sensitive information from people who live in fear.

\subsection{Sampling Design}

The issues that the researcher explores in this study emerge from his position for an individual. Being fled his home country and victimized by the Eritrean government, position him to disclaim neutrality. This research will reflect some of his own first-hand experience as a result of a number of years' active participation over the life of Eritrean Diaspora as a journalist and human right activist as well as the experience of refugees and activists. 
The researcher uses maximum variation sampling (Creswell, 2013) to gather a wide range of information about the issue of coercive transnational governance and its impact upon the resettlement process of refugees. Based on that strategy the researcher recruits eight Eritrean refugees who arrived in Canada within the last 20 years and one human right activists, and two individuals from law enforcement authorities. The 8 participants are selected because they currently dealt or have dealt previously with the Eritrean consulate for any type of service. Moreover, the two activists are selected because they have been vocal about the issue for a number of years consistently. The two law enforcement agents were approached due to the relevance of their work in deterring organized crimes.

The recruitment poster of this research was circulated among the email group and facebook page of Eritrean community, and posters were distributed in the Eritrean restaurants in Toronto. Moreover, the researcher extended invitation letter via e-mail to 95 his network to participate in the study. The desire of the participants to share their personal experience was overwhelming. No coercive method was used. Eleven participants agreed and gave their written consent for the interview and audio-recording, and the interviews were conducted accordingly.

\subsection{Data Collection Method}

The researcher collected the data through an open-ended, and semi-structured interview. This was the best method to document each refugee's story in-depth. The participants were asked follow-up questions to the initial response they provided to elaborate certain points and give examples based on their personal experience. Efforts were made to capture very important phrases of the participants by taking notes. 
The participants of this research were refugees who consider themselves as victims and activist that advocated on behalf of Eritrean refugees. During the interview, they shared the date of their arrival in Canada and the challenges they faced initially. The participants spoke about their resettlement experience in detail. The researcher asked how the role of the Eritrean Consulate in Toronto affected their lives, the services' participants requested or acquired from the consulate, the harassment or intimidation they experience, if they reported to police about coercive activities of the consulate and if they have any recommendations on how to address/solve this issue. The interview with the human right activists focused in capturing their perspective on the issue refugees complained about the obstacles they faced during the resettlement process, the role of Eritrean Consulate in the life of Eritrean refugees; if the activists have made any effort to disclose the problem and the challenges, they face.

The participants were proficient in English, but the interviews were conducted in English or Tigrigna (based on the participant's preference). One interview which was conducted in Tigrigna, a thorough transcription and translation were made afterwards. Most of the participants responded the interview questions in writing, but follow-up questions were answered on the phone and audiotaped based on the consent of the participants. Each of them lasted about 15 to 25 minutes. All interviews were conducted during the months of August, September and October in 2015.

This research has been reviewed and cleared by the Ryerson Research Ethics Board (RREB) after the proposal was submitted. The ethical aspects of the research such as confidentiality and privacy, risk assessment, methodology, how and where to conduct interviews, were examined. The email invitation letters to potential participants, recruitment poster and written consent form of 
participants were approved by the RREB. The formulated consent form ensures the participants' right to withdraw from the interview or skip any question if they feel uncomfortable.

The interview questions can be found in Appendix 1.

\subsection{Data Analysis Method}

The interviews were transcribed; the documents and notes were reviewed before the start of analyzing the data. The researcher created 11 categories to classify the collected data. As Creswell (2013) asserts, 'these codes can represent: information that researchers expect to find before the study; surprising information that researchers did not expect to find; and information that is conceptually interesting or unusual to researchers (and potentially participants and audiences)'(p. 186).

The participants and the cases were described. The ideas and views of participants were categorized in a table to recognize the major points for analysis. The concepts extracted from the 11 categories, were interpreted and condensed into more general four themes - state of fear, dilemma to seek help from law enforcement agents, stumbling block and financial burden. A constant comparison was made to identify the pattern, highlight the impact of one theme to the other, and a short summary of each theme was also presented. The researcher's analytical memos were indicated in the final part of the research.

\subsection{Validation strategy}

Qualitative research methods use the systematic way of gathering data, categorization, and find accurate meaning of the collected documents through interviews or participation or observation (Malterud, 2001). To ensure the credibility of the study, the researcher applied validation strategies 
of triangulation, reflexivity as well as a detailed description of the issues and consultation with the participants.

The researcher fled Eritrea after the government shut down his newspaper and came to arrest him. This research includes some of his personal experience beside the long list of participants' experiences and that has position him to disclaim neutrality. However, he has challenged his own biases and theoretical tendencies so as to provide the most accurate description of the research he has endeavored. To further assessing the validity of this study, he has utilized the 20 criteria of 'critique checklist' (Stake, 1995: 131):

1. Is the report easy to read?

2. Does it fit together, each sentence contributing to the whole?

3. Does the report have a conceptual structure (for example, themes or issues?)

4. Are these issues developed in a serious and scholarly way?

5. Is the case adequately defined?

6. Is there a sense of story to the presentation?

7. Is the reader provided with some vicarious experience?

8. Have quotations been used effectively?

9. Are headings, figures, artifacts, appendixes, and indexes used effectively?

10. Was it edited well?

11. Has the writer made sound assertions, neither over-nor under-interpreting?

12. Has adequate attention being paid to various contexts?

13. Were sufficient raw data presented?

14. Were the data resources well-chosen and in sufficient number?

15. Do observations and interpretations appear to have been triangulated?

16. Are the role and point of view of the researcher nicely apparent?

17. Is the nature of the intended audience apparent?

18. Is empathy shown for all sides?

19. Are personal intentions examined?

20. Does it appear that individuals were put at risk? (Stake, 1995: 131) 


\section{Research Findings}

\subsection{Introducing the Participants}

The participants will be introduced and referred to by numbers in this section based on the sequence of their interviews.

Participant 3 came to Canada in 1999. Like many immigrants, he faced challenges in getting his credentials recognized and finding a job relevant to his education and skills. After he acquired a post-graduate degree in Canada, he managed to overcome his challenges and was able to land a better job.

He knew he wouldn't get basic services without fulfilling the demands of the Eritrean Consulate in Toronto. Because he openly opposed the practices of the consulate as a human right and refugee activist, he has never requested any such services. He gave up inviting his parents to visit him in Canada because they wouldn't get an exit visa from the Eritrean government unless he paid $2 \%$ tax of his annual income and signed a regret form. As a result, he hasn't seen his parents for 16 years since he arrived in Canada.

Participant 4 came to Canada in 2004 and claimed inland refugee status. She faced several settlement challenges such as lack of access to affordable housing and settlement funding (transitioning loan), lack of access to professional mentorship, and most of all, a lack of basic services from the Eritrean Consulate. 
She has a Bachelor's degree from the University of Asmara. As soon as she was accepted as a refugee and decided to pursue her education, she contacted the University of Asmara to get her transcript. The university advised her to give them a clearance letter from the Eritrean Consulate in Canada. She visited the Eritrean Consulate in Toronto and asked them for a clearance letter so that she could request her educational documents from the University of Asmara.

The Consulate asked her to sign an 'Immigration \&Citizenship Services Request Form’ or better known as a regret form (a form that forces people to confess that they left their country illegally) (see Appendix 3), and pay 2\% tax of her annual income from the day she had arrived in Canada. She refused and so she did not receive a clearance letter. As a result, her plan to pursue her education in her field was delayed for about four years.

Participant 5 came in 2008 leaving his family behind. He claimed refugee status in Canada. He faced challenges in finding a job due to his refugee status and language barrier like many newcomers. However, his biggest challenges came from the Eritrean Consulate which refused to provide him with services.

He is married and has children who were still living in Eritrea. He wanted them to join him in Canada after he got a permanent resident card. His wife applied for an exit visa but she was told that if her husband wished to fulfill his duty, he had to provide a clearance letter from the Eritrean embassy in Canada. He went to the Eritrean Consulate in Toronto and asked for a clearance letter to secure an exit visa for his wife and children. 
The Consulate asked him to pay $2 \%$ tax on the income he had earned since his arrival in Canada, sign a regret form for defecting his country and donate money for the country's defence. He refused to comply with the request of the Consulate and his family was denied exit visas. As a consequence, he smuggled his family to a neighbouring country and then brought them to Canada. The entire reunification process took eight long years.

Participant 7 came in 2006 leaving his family behind and claimed refugee status when he entered Canada. His settlement process was generally positive and fast. After he was accepted as a refugee, he immediately attended post-graduate studies, which allowed him to have a smooth transition with regard to employment. However, he had challenges in reuniting with his family due to the obstacles created by the Eritrean Consulate in Toronto.

He had a wife and children who were then living in Eritrea. He decided to bring them to Canada after his asylum claim was accepted. He went to the Eritrean Consulate in Toronto and asked for a supporting letter so that his wife could get an exit visa from Eritrea.

The consulate assured him his wife would receive an exit visa if he paid $2 \%$ tax of his annual income and signed a regret form. He refused to do either. As a result, the reunification with his family was delayed for years. He finally succeeded in smuggling his wife and children to a neighboring country and then brought them to Toronto.

Participant 8 came to Canada in 2010 to reunite with her family. Her settlement process was relatively smooth as she didn't have to deal with refugee claimant issues. Moreover, the support 
she received from family members and settlement agencies helped her to re-launch her life with fewer obstacles. Nevertheless, she had other challenges that came from the Eritrean Consulate in Toronto.

She contacted the Eritrean Consulate in Toronto in 2014 to renew her expired passport. The consulate asked her to bring a tax statement that she had filed with Revenue Canada and told her that she would have to pay $2 \%$ of her annual income since she had arrived in Canada. After making the calculation, the Consulate told her on the phone to send the payment in cash to Eritrea. She asked them to provide her with an easy and legal way to make her payment but they weren't interested in assisting her unless she made the payment first. She refused to pay.

Participant 9 came to Canada in 2001, leaving his wife and child in Eritrea. Besides the common challenges most newcomers face, his settlement process was even more difficult because he had a disability and he had to claim refugee status. After he secured his conventional refugee status and later his permanent residency, he wanted to sponsor his family to be reunited with him. His application for family reunification took years because of the slow process caused by the Canadian government. When that frustration was finally over, the application was completed and his wife was ready to come to Canada. However, he still had to overcome his biggest obstacle - the Eritrean government.

The Eritrean government denied his wife an exit visa. They told her that she needed a clearance letter from the Eritrean Consulate in Toronto. Her husband was forced to visit the Eritrean Consulate in 2004 to get the clearance letter. He was ordered to provide a pay stub that would help 
the Consulate to calculate his annual income. He had to pay $2 \%$ of his annual income for the years he had worked, and $\$ 5$ for every month he had been on social welfare. He was also asked to sign a regret form for fleeing his country. He didn't want to comply with their request because he thought it was outrageous. However, he realized that he had no other option. So he paid 2\% of his annual income and reluctantly signed the regret form (see Appendix 3). A few months later, his wife and child were allowed to leave Eritrea and be reunited with him.

Participant 10 came to Canada in 2007 as a sponsored refugee. Like many newcomers, his settlement process was difficult. He had challenges in navigating the Canadian system, finding employment and dealing with the cold Canadian weather. He was also puzzled by some members of the Eritrean community who tried to recruit him to support the regime he had fled. What frustrated him most was finding employment because he lacked the educational documents for the field in which he was trained. He was denied access to his transcripts from the University of Asmara and the letters indicating his work experience at the institution in Eritrea because he didn't provide a clearance letter issued by the Eritrean Consulate in Toronto.

He contacted the Eritrean Consulate in Toronto to assist him in getting copies of his educational documents from the University of Asmara. The office ordered him to make a payment of $2 \%$ of his annual income. Knowing there was no other way to secure his educational documents from Eritrea and restart his career in Canada, he paid the amount that he was asked. He has left the rocky settlement experience behind him. He is now pursuing his career and leading a comfortable life.

Participant 11 came to Canada in 2008 via the United States of America. He had an encounter with the Eritrean Embassy in Washington DC when he wanted to renew his expired passport before 
he came to Canada. The embassy told him to sign a regret form for leaving his country without the permission of the Eritrean government. He had no other choice but to sign the form.

As soon as he entered Canada, he claimed refugee status. But he had to wait months to hear the result of his application. His settlement process was disturbing because he lacked refugee status and he feared deportation. Since he had already signed the regret form that declared he was a traitor, his worries were huge. That's why he felt extremely relieved when the Immigration and Refugee Board of Canada accepted him as a conventional refugee after a year.

Officer 1 works with RCMP. He has more than 20 years of experiences in issues related to crime operations.

Officer 2 works with Toronto Police. He has more than 10 years of experiences in the field.

Activist 1 came to Canada in 2005. He has been advocating for refugees and been involved in Eritrean human rights issues since his arrival. He assists refugees in navigating the system and helps them overcome their challenges by providing advice or guidance. He also speaks on their behalf whenever they encounter obstacles, particularly from the representatives of the Eritrean government in Canada.

He hears a number of complaints about the activities of the Eritrean Consulate in Toronto. One of the refugees shared with the Activist the challenges he had faced in bringing his wife to Canada in 2015. The refugee's wife was refused a passport in Eritrea because her husband who lives in Canada didn’t pay the 2\% tax on his income. The husband didn’t want to pay so he smuggled his 
wife to Sudan. His wife applied for a passport at the Eritrean Embassy in Sudan but she received the same answer. The husband, frustrated by the situation and left with no other option paid $2 \%$ of his income. "I had savings of $\$ 10,000$, but all has gone into this thing."

\subsection{The Fear That Shadows Eritrean Refugees}

All participants fear for the safety of their family members who live in Eritrea. They believe that any activity they engage in Canada can negatively affect the fate of their family. They don't feel free or secure to reject or criticize the demands of the Eritrean Consulate in Toronto despite the protection they are provided by the Canadian government.

Participant 5 explained the state of fear extends to the community as a result of the activities of the Eritrean Consulate. He noted:

The office asks every individual to pay $2 \%$ tax, donate money and the worst thing is the fear they have instilled in many Eritreans who live here. This makes all Eritreans suspicious of one another. You can't tell anyone what you think about Eritrea because your family who lives in Eritrea can run the risk of being affected negatively.

Similarly, Participant 3 described the nature of the Consulate work as follows:

The Consulate and its employees spy on members of the community and report any activities that are considered anti-Eritrean Government. 
Participant 9 stated that the main targets of the Consulate are refugees. He pointed out:

...they were taking advantage of refugees, especially refugees, because they know that we have left people we love behind... I cannot oppose what the Consulate is doing because I know I have my family back home. This was the first reason. The second reason was when I wanted to bring my family here, I had to go to the Consulate. If I don't go to the Consulate, then I cannot get my wife or my son, or any parent from Eritrea.

For any refugee who fled the government of his/her home country, it can be mind-boggling to find himself/herself systematically under the control of the regime. Participant 10 shared what he experienced in the second week of his arrival in Canada that shocked him to the point of complete disbelief.

In the second week of my arrival, someone whom I met at church introduced me to the leader of the Eritrean community who then invited me to a meeting which would take place the following week. I thought this guy was a leader of a non-political community but when I went to the meeting to which he had invited me, the guest speaker was Mr. Semere Okbamichael, who was then the Canadian consul. His speech gave me nightmares about the brutality of the Eritrean regime. It continues even here. When I left the meeting, I cried all the way home. What he was saying was that everyone has to be up to date in paying the $2 \%$ tax and every household has to pay $\$ 500 \mathrm{CAD}$ to fund the Eritrean defence forces. (Participant 10)

Participant 8 described the intimidating role the Consulate plays. She noted: 
They threaten the people not to express their voice against the Eritrean government and force them to pay $2 \%$ of their income.

Participant 7 also stated the fear he felt whenever he visited the Eritrean Consulate in Toronto to request an exit visa for his wife and children. He explained:

...every time I go there to explore the option, the staff use an intimidating approach...if you don’t do this, you will fear for your family kind of attitude. This, by itself, creates a lot of psychological pressure.

Most participants live under constant fear as they worry about their loved ones. That's one of the main reasons some of them didn't want to report the extortion they experienced to law enforcement agents.

The analysis of the participants and activists clearly reveals that the Eritrean Consulate in Toronto is in the business of spying upon community activities. As a result, people from Eritrea live in a state of fear to protect their family members who still live in Eritrea. They censor their conversation, monitor their activities and restrain themselves from complaining to Canadian law enforcement agencies for fear of retaliation to their loved ones by the Eritrean government. Even though they live in this free and democratic society, they don't feel liberated. 


\subsection{Dealing with law enforcement agents}

There is a huge lack of trust in the way police work in less developed and post-authoritarian countries (Mishler and Rose, 1998; Goldsmith, 2005). Immigrants who came from those regions tend to distrust police due to their previous bad experiences and may not initially approach police for help. However, this was not an issue for the participants of this research.

Most participants live under constant fear of the regime they left behind as they worry about their loved ones who still live in Eritrea. That's one of the main reasons some of them didn't want to report the extortion they experienced to law enforcement agents. They articulate the complexity of the issues as follows:

I and many others prefer to keep quiet because, for any action that is taken by me or someone like me here, our parents will eventually pay the price. They will get detained and have to pay a hefty amount of money. This is practiced widely in Eritrea and, unfortunately, for that reason, many who have loved ones in Eritrea prefer to keep silent. (Participant 11)

I didn't approach Canadian authorities. Sometimes when you approach the police, you wonder are you also going to have to give evidence? Will you be called as a witness? Will it be done quietly? The fear is I have my entire family in Eritrea. (Participant 3)

If I went to the local police or RCMP and told them about the problem, the RCMP will go to the Eritrean Consulate to make inquiries. What I am scared of is not for myself. I fear I'm placing the lives of my family and my parents at risk. (Participant 5) 
The front and centre of those refugees' fear is that they don't want their family members to be punished by the Eritrean government for the complaints they file in Canada. They don't want their issues to end up in a public domain so that the Eritrean regime retaliates against their loved ones. However, officer 2 assures things can be done confidentially although he also highlighted further assistance would be needed by the victims to push cases forward. He noted:

Your complaints are a confidential matter between you and the police. If you complain about someone who is intimidating you and harassing you, the police can go to them to hear that person's side of their story too. We realize it is difficult situation. The best thing to do in these circumstances is to take notes about what happened to you, why you think it happened, who did it and present that to the police. You can go to any police station in Toronto. There are 17 police stations where you can report the crime. If you have trouble with English, you can bring somebody who has a better understanding of English to interpret on your behalf.

According to Activist 1, besides the fear that shadows the refugees' day-to-day life, lack of knowledge of the Canadian system could be an issue for some refugees which prevents them from reporting their problems. He noted:

The problem lies with the mentality of some of our people. So far, they haven't been really liberated, partly because some of them do not know that the law exists to protect them. Then, to some extent, they are so afraid and chained by fear. It's proving to be so challenging for them to break through their fear. (Activist 1) 
Likewise, Participant 7 stated that lack of awareness was his main reason for not approaching the police at the beginning:

I didn't have the awareness to complain about such activities at that time. (Participant 7)

If law enforcement agents are not informed by the victims due to fear or lack of awareness in the first place, it will be hard for enforcement agents to do their job properly. Officer 2 articulates what should be done. He said:

If people are intimidating you for money, they can be charged criminally. It is up to victims to come forward to speak with the police and make their complaints in the first place. If victims cooperates with us, want to push the issue forward, and if we can bring them to court, we will need their cooperation to make a case. If there is a language or cultural barrier, and if there is no trust in the police in the countries where they came from. . . But in Canada you have a right to make those complaints. You have the outlet to do it. And we realize at the end of the day, it is not an easy thing to do. It is not easy to come forward, especially if you feel intimidated.

However, for some victims it was not difficult to file their complaints to the police.

I reported all my concerns to the RCMP. (Participant 8)

At one point I reported my complaints after I welcomed my wife and son. I think I called a police station to report this. They said, 'this is not something we can help you with. You paid them yourself. Nobody forced you to pay.' I don't blame them because they think that everybody in Canada makes the choice to pay or not to pay. In our country it is a different 
situation. So, I couldn't say anything after that. They were not supportive. So, I didn't push forward. And I stopped my claim at that time. (Participant 9)

I reported to the police once when the demonstrators who support the Eritrean regime smashed my car. Also on several occasions I spoke to Canadian government officials and the media about what the community does to collect the $2 \%$ tax to support the Eritrean Defence Forces. (Participant 10)

The way the RCMP or police handles the complaints filed to them encourages or discourages Eritrean refugees from coming forward. Specific examples would have helped to shed more light on the issue. However, both officers did not want to talk about specific issues due to privacy and lack of information concerns.

In the course of responding to complaints, RCMP investigators routinely speak with persons to help determine if the reported allegations have any substance. If it is determined that an investigation is warranted, one will be initiated. In order to protect the integrity of the investigation, the evidence obtained, and the privacy of those involved, the RCMP generally will not make any comments during the course of an investigation. In some circumstances information might be provided to the public, for example in an effort to seek further information from the public. Generally, only when an investigation results in the laying of criminal charges, will the RCMP confirm its investigation, the nature of the charges laid and the identity of the individual(s) involved. Should the investigation not generate sufficient evidence to support the laying of criminal charges, the RCMP will close their file and, in most cases, they will privately advise the complainant of this result. (Officer 1) 
I don't know, if I can speak about any specific cases. In any case I mean, especially given the privacy of everyone involved, I don't have any knowledge of that myself. (Officer 2)

To simplify the way refugees report their concerns or file their complaints, it is crucial to have a specific unit or at least contact persons in the law enforcement agents that understand the complexities of the refugees' issues. Officer 2 indicates there isn't a specific unit but he says there are several units that can offer their assistance. He stated:

We have a unit called a division of police support unit, but as I mentioned, there is nothing specific to the Eritrean community, but they have various consulting services, a division of support unit and a newcomer outreach. We have a consulting community for the African, Chinese and Moslem communities. Generally, we invite the leadership of the community or social organizations that work with the community to give their input with regard to their community concerns... But at the end of the day, every police officer should be able to go to any home where calls about domestic violence have been made. They should be able to go into homes and offer services to the victim. They should be able to offer their services to any victim. They should be able to have a way to do that. We can't have 5,000 Eritreanspeaking police officers. We certainly have to be sensitive to the fact that people have come here from other places, and they may not trust us right away. That's something we need to understand.

The law enforcement agents may take adequate training to serve Canadian society. As the demography of the country changes rapidly as well as the nature of the crimes, they may have some catching up to do to deal with the immigrants' issues. Though participant 9 didn't blame the 
police for not supporting his complaints when he approached them for help, he underlined their lack of understanding of the issues. How informed are police about the transnational nature of community politics, harassment, intimidation and the controversial fundraising activities?

We have a lot of different training: online training to understand a little bit about religion and different cultures. To say we gain an in-depth knowledge in our training is incorrect. Our training is not that extensive. You mention potential political corruption. That's pretty deep. Eritrea, Italy, we don't have specific training. As far as I know, being sensitive to that is certainly part of the training. (Officer 2)

The bottleneck of most participants of this research for not reporting their complaints to law enforcement agents is the fear of repercussion to their family members by the Eritrean government. They are afraid to testify or act as witnesses for the police because of their loved ones who live in their country of origin. Refugees articulate that their family members can be tortured as a reprisal. Meanwhile, the Canadian law enforcement agents will always need the cooperation of the victims to push cases forward and resolve issues. The agents may guarantee the safety of the refugees in their jurisdiction, but not their families who live outside Canada. The participants know that and that's why they don't come forward to seek help. Unfortunately, the patronizing response of the officers and their vague statement to the pointed out questions give little clue on how they can protect victims and investigate the incidents to the satisfaction of justice seekers.

\subsection{The Stumbling Block of Settlement}

The readiness of the receiving society in accepting refugees is crucial in determining whether those refugees will ‘sink or swim’ (Joly, 1996; Lam, 1996; Danson, 2002). If they encounter a number 
of obstacles in the initial stages of their settlement, their integration process could be hindered (Lam, 1999; Danson, 2002). Though many participants stated they had challenges in launching their lives in Canada due to lack of employment or refugee status in the first year of their arrival, the roughness of their journey was bearable. They could overcome their challenges one after the other. The insurmountable challenges they faced came from the Eritrean government via its representatives in Canada. Most of the participants described them as the biggest barrier of their lives.

Participant 4 stated her plan to pursue her higher education was delayed for about four years due to the obstacles of the Eritrean Consulate in Toronto. She noted:

I was denied access to my own documents that I had worked hard for and earned. My education plan was delayed for years due to the lack of support from this office... If I were able to start as per my plans, I would have graduated in 2007.

Activist 1 provides example similar to what Participant 4 experienced. There was another refugee whom the Activist assisted in finding a job. The refugee requested his transcript from the University of Asmara in 2015 but he was denied because he didn’t provide a letter of support from the Eritrean Consulate in Toronto. Since he was not willing to pay $2 \%$ tax of his annual income and sign a regret form, he dropped his request for the transcript.

Participant 5 described the stressful time he spent in facilitating the escape of his family from Eritrea after the Eritrean Consulate refused to assist him unless he paid the $2 \%$ tax on his income. He noted:

When I decided to bring my family out, I just took a 50\% chance, either to smuggle them successfully or lose them. They can be killed by the government soldiers when they try to 
escape from the country. There are soldiers who patrol the border day and night. If the smugglers tried to smuggle them while the army are on duty, they can kill them. There is a shoot-to-kill policy in the country.

The other thing is the issue of smugglers. You have no idea, whether they are independent or whether they work for the government. So they can take your money and not bring your family or they can sell them to other smugglers. The risks are huge. So it is a fifty-fifty chance. If I am lucky, I have a 50\% chance of seeing them safe. If I'm not, I could lose them forever.

He got lucky; he smuggled his family successfully in 2015 and he was reunited with them after eight years of separation.

Participant 7 articulated the biggest challenges he went through to smuggle his family after the Eritrean government refused to give exit visas to his wife and children. He said:

I would say the consulate is creating a number of obstacles in Eritrea not to reunite families. The first challenge was, the route they would travel was risky. It's a life -and- death situation. If they managed to be successful they would get their life. If not they would lose their life. It's as simple as that but far more risky than you can imagine. If they were caught during the journey, they can be arrested. Or if they tried to run away, because of the shootto-kill policy, they can be killed.

The second challenge is financial. Obviously you have to pay the smugglers in US dollars and this is in the thousands. That's another major challenge. 
Many people cannot see the third challenge. The whole process was psychologically traumatic both for my family and me. The effect has long-term consequences. I was in a constant state of psychological turmoil and stress, which lasted for a very long time. In fact, it can affect not just your health and psychological well-being, but also that of my family.

If you take into account all these things, we're talking about a whole family—my wife and three kids. The stakes were very high and I've always wondered how we even managed it. When we talk about my three kids, the youngest one was just three while the oldest was nine years old. If you also take into account that the area they were planning to cross was a desert with very minimal water supply and a lot of unknown factors, one can understand how grave the situation was. That made the whole situation extremely challenging.

Deciding to take on this challenge is a challenge in itself. What makes it challenging is because I knew firsthand from my own experience what it looked like. It reminded me of my own route. Some Eritreans who decided to take that route do not know what it looks like but I know. I knew firsthand the route I had taken. That made it very hard for me. Even though I could run and do a lot of things as I was just by myself, the desert was still unbearable. Can you imagine how it must have felt for my wife and three kids to cross the border and travel through the desert?

Participant 8 remembered the hindrance she faced in her travel plans simply because she didn't fulfill the request of the Eritrean Consulate in Toronto. She stated:

I had a plan to travel (with my Eritrean passport) from Canada for an urgent matter but I was not able to travel. So I applied to the Canadian government for a travel document. I 
explained to them that the Eritrean government refused to renew my passport unless I paid the $2 \%$ tax on my income. Then they asked me to present a written legal document from the Eritrean government, saying that they had refused to renew my passport because of that. However, the Eritrean Consulate didn't want to give me a written document and the Canadian government didn't understand. It was very challenging. So I had to go to my Member of Parliament to get help. It was a long process. Because of that, my travel was delayed for about five months. But I couldn't afford to wait five months.

Participant 10 articulated that the Eritrean Consulate interfered in the business of the community centre that provides settlement services to newcomers. This represented an obstacle. He noted: The concern I have with the consulate is that they mix their consular business with the community groups which are supposed to be non-partisan and non-divisive, focusing on the settlement needs of newcomers. To Canadians, the Canadian government and the media, these groups look like communities from outside but they are politically polarized; they use different tactics in isolating people who speak up about what happened to them under the regime. The Consulate also spreads rumors to scare and control others who might follow in the same path. They use scare tactics to threaten to retaliate against family and refuse to provide services that are meant for all newcomers. Instead they only assist those who are loyal to the regime, declining to give birth certificates, education papers, etc. to others.

Participant 11 questioned the legitimacy of the Eritrean Consulate in the way it served newcomers. He said:

All its services are provided to members (not citizens) who abide by the conditions of the consulate. Such conditions include payment of the $2 \%$ tax or other benefits to the regime 
in Eritrea. It is deplorable to learn that to even get a copy of your degree or high school certificate from Eritrea, you have to go through the consulate.

Participant 9 stated one of the biggest challenges he faced from the Eritrean Consulate was when he was asked to sign the regret form so that his wife would be granted an exit visa. He noted:

If I don't sign, the first thing that could happen is they are not going to allow my wife to leave the country and the second thing they can do is take revenge. My wife can become a victim as revenge against me.

I signed the form even though I didn't accept it morally. This was the worst part of my experience about the Eritrean Consulate in Canada.

Most participants articulated the challenges they faced from the Eritrean Consulate in re-starting their lives in Canada. They were blocked from accessing their educational documents and, as a result, their plans to pursue their education was delayed for years. Their families were denied exit visas to leave Eritrea and most of the participants were forced to separate from their loved ones for a number of years, taking dangerous routes to smuggle their families from Eritrea. The refusal by the consulate to renew passports or other original documents were major obstacles in launching their lives as refugees in a new country.

\subsection{Financial Burden}

Overall, refugees have more difficulties accessing affordable places to live in and finding a wellpaying jobs (Hielbert, 2011). As a result, their income is low and their stress level is high. They struggle to make ends meet for themselves "while sending provision abroad to support family members who have been left behind” (Hiebert, 2011). The financial difficulty of some participants 
of this research is a living example of a person who has been stripped financially. They are not only exposed to common challenges of refugees in creating a secure income but are also forced to pay $2 \%$ of their income to the Eritrean regime. They were obliged to pay for irrelevant services. The Eritrean Consulate in Toronto forces them to pay a percentage of their annual income if they wish to request birth certificates, power of attorney, educational documents, marriage certificates or exit visas for family members. This process breaks the financial backbone of many refugees right at the very beginning.

Participant 10 highlighted his experience elegantly. He was asked to pay $2 \%$ of his income and other fees to get his educational documents from the University of Asmara. He said:

When a new person arrives, there are so many costs which overlap one on top of the other. There are transportation costs, rent and other expenses. On top of that, my wife was pregnant. She gave birth two months after our arrival. So I was the only one who was working. In general, I paid around $\$ 1,000$ for the $2 \%$ tax. In addition to that, there was a processing fee and then, I also had to pay money to the University of Asmara. Moreover, I didn't have a stable job. As a newcomer, you don't have any savings. Yet, you have to cover the grocery, rent and everything you need for the baby. It was not easy.

Activist 1 provides example of one of the refugees that he assisted them. He noted:

There was one Eritrean who came to Canada as a government-sponsored refugee from a prison in Egypt. This was about four years ago. You know, I was helping him along with other friends of mine. There were about 49 of them who came at that time. This guy left his wife and three children behind. He was getting some support from the Canadian government as he was a government-sponsored refugee. At the time when he was trying to 
bring his children and his wife, he was asked to pay the 2\% tax that's imposed on Eritreans living abroad. He was willing to pay the $2 \%$ tax. Obviously, people will do whatever they need to do to be reunited with their loved ones. So, the funny thing was, he was asked... When the calculation of the 2\% tax came, even the time he had spent in Egypt was taken into consideration by the representative of the consulate at that time. To me, it is nonsense.

The second thing is at that time he himself was dependent on the Canadian government. In other words, your money and my money as tax-payers was taken away by the consulate. That's what surprised me. (Activist 1)

Participant 9 depicted a vivid picture of the issue. What surprised him most about the behaviour of the Eritrean Consulate was their lack of consideration for disabled people and individuals who live on social welfare. The office forced everyone to pay regardless of the individuals' situations. He stated:

You can imagine. I was sending money back home just to help my wife and child, and I was helping myself because I didn't have anyone to cook and clean my house, everything. So, my cost was doubled like everyone else. They didn't even consider my personal challenges as a disabled person. The consulate was looking after my money, not after me as a person or a citizen.

He was charged $\$ 5$ a month for the two years (2001-2003) when he was on social welfare and 2\% of his income for the few months that he had worked.

All in all, I paid over $\$ 290$ at that point. So, it was good for me because I know there are people who paid over $\$ 5,000$ or $\$ 6,000$ from their income. I was so lucky. My damage was not too much but still it was not legal. (Participant 9) 
Participant 9 might be lucky as his wife and child were granted exit visas after he made the payment. However, many of the participants believe that doesn't work for everyone. They don’t receive any guarantee from the Eritrean regime. So they take a huge life and financial risk by dealing with smugglers to secure the escape of their family. Participant 5 described the financial burden he shouldered to secure the escape of his family. He said:

In the last eight years that I have stayed here, I have spent more money to pay for their escape than what I spent to feed them while they were in Eritrea. You are forced to spend your four-year income for such a purpose because there is no other choice. It drains you financially and leaves you without any money. A long time ago the demands of the smugglers were small but from time to time, they have increased the price just as they please. Therefore, one of the biggest challenges was the financial issue. I was forced to pay US\$20,000 to the smugglers.

Participant 7 just finished his graduate studies and began working on a contract basis while conceiving the idea of smuggling his family. Despite his dire financial situation, he had to do anything to reunite with his family before things get worse in Eritrea. He noted:

Literally I didn't have enough money to meet all my financial needs. So, what I did, I had to ask my friends and relatives for credit because I can't finance it with my credit card. I have to have cash, so I have to rely on friends and relatives who wish to reunite me with my family. It doesn't necessarily mean they have lots of money but they support my mission and plan and I am very grateful for that.

Dealing with smugglers for the escape of loved ones is a risky business. Participant 7 knew that could jeopardize the life of his family and it could drown him financially but he had to do it as a last resort. He said: 
One might ask why you wanted to make such a difficult decision at the time. But if you know Eritrea, yesterday was always better than today and today is better than tomorrow for sure, so we have to rush because of the deteriorating situation. It is a race against time. ...generally it was expensive. It is not just about the money you spend to pay the smugglers. There are many unknown situations you have to deal with financially as well. For instance, once they crossed the border, the smugglers increased their demand for money. For instance you would agree to pay $\$ 6,000$ for a family. As soon as the smugglers get them in their hands, they would say they want $\$ 10,000$. I actually had that challenge. As soon as my family crossed the border of Sudan, the smuggler told me through an interpreter that I was not going to get my family unless I paid $\$ 10,000$. I told him that we had agreed to pay him $\$ 7,000$. What are you talking about? We negotiated a lot. It is not a normal negotiation because your family are already in their hands and you don't know what will happen to your family. So they put you in a very difficult position. Your family doesn't know your situation either, whether you have money or not. They don't understand and they are right because it is about their lives. It was a very nerve-wracking time. I don’t know how to describe it, but it was very challenging.

The challenging process ended up with his victory. He managed to reunite with his family after four years of separation.

The tremendous amount of money that refugees are forced to pay the Eritrean Consulate or smugglers to unite with their family is a real drain on their resources. This money could have been used to ease their financial challenges instead. Participant 7 articulated what he could have done with the money he paid to smugglers. 
On a personal level, I could have used that money to pay off my student debt. I could have spent that money at that time to obtain better housing. Considering the Eritrean side, I would have preferred to give that money to the government if it is a responsible government. They can then use the money for the public good. Instead smugglers use that money and you don't even know where that money goes, whether they are terrorists or not. Even if it is very expensive, I would prefer to pay the government if they asked legally. I would prefer to pay them instead of putting my family in danger. Financially, of course, it is very expensive, but no amount of money can buy a life. (Participant 7)

Activist 1 also painted a similar picture about his client experience. The refugee whom he was assisting him was forced to pay $\$ 10,000$ to the Eritrean Consulate to secure an exit visa for his wife.

Now as far as I'm concerned, if that money were here, that person could have used that money to invest in building his skills or use it as a down payment for his home, which takes him away from being a burden to Canadian society. Or the money can also be used for the Canadian community for that matter. So, you see the impact is so great. (Activist 1)

Much has been discussed about the monetary challenges newcomers face due to lack of adequate employment or financial assistance in the previous literatures. The barriers they face are huge as they struggle daily to put bread on the table. That's a common challenge of most refugees. However, the difficulty for most participants of this research is much bigger than that. They sink into financial crisis right from the beginning. On top of the burden every newcomer carries, they are forced to pay $2 \%$ of their annual income to the Eritrean Consulate for services that are irrelevant to their needs. It's a pre-condition payment to get their documents from Eritrea and exit visas for their family. Some of them were also forced to pay the smugglers to get their loved ones out of 
Eritrea. They put themselves into debt to assure the reunification of their family. This heavy financial burden hinders their settlement from the very start and it takes them a while to fully recover.

\subsection{My Personal Settlement Experience}

I fled my home country, Eritrea, after the government shut down the newspaper I had co-founded and came to arrest me. Luckily, I was granted asylum in Canada at the end of 2002. I thought I was out of the reach of the Eritrean regime, but I was wrong. My brother and cousin were arrested as a reprisal for two years and none of them were charged or brought to a court for trial. The Eritrean Consulate in Canada was trying to control my activities by using direct or indirect intimidating tactics. As soon as I started a community newspaper in Toronto called Meftih in 2004, I experienced acts of intimidation, vandalism, social isolation, and hurdles to being reunited with my family. All these obstacles imposed by the Eritrean Consulate impacted my settlement process negatively.

\subsubsection{Intimidation}

The authoritarian regime of Eritrea instills a 'climate of fear' in the Eritrean Diaspora to 'paralyze migrant communities' (Popkin 2003, p. 369). I am a prime example of such intimidation. One of the things I did was to publish critical remarks about the Eritrean regime in Meftih. One event I wrote about that touched the nerve of the Eritrean Consulate was my coverage of the annual Eritrean Festival in Toronto. The festival organizing committee and the Eritrean Consulate are two flip sides of the same coin. They operate from the same office in the consulate which is located in Suite 309 at 120 Carlton Street, Toronto, ON. In the October 2006 issue of Meftih (See Appendix 
6), I criticized the overall preparation of the Eritrean festival in Toronto, which is usually held in August. Every year, the festival is organized as an Eritrean community, but the community is hardly involved in organizing or setting the festival's agenda. I highlighted the lack of transparency of the Eritrean Consulate and its manipulation of the community. I articulated that the festival is organized by a few individuals who are hand-picked by the Eritrean Consulate. I pointed out that the organizers didn't address the social issues of the community, but instead focused on making financial profits or addressing the political agenda of the Eritrean government. I received several intimidating calls from unknown numbers: '...we will bury you with your paper'; '...you will pay the price of your actions'; '...we know where you live,' etc.' I informed the police and presented a list of possible callers since I didn’t have concrete proof. I was advised by the police to return with more evidence.

When the annual Eritrean festival of 2007 approached, the chair of the festival organizers who is also the chair of the Toronto branch of the ruling party (PFDJ), sent me a letter via email on July 19, 2007 (see Appendix 7). In his letter, he told me not to attend 'any venue of the forthcoming Toronto Eritrean Community Festival 2007', adding that it was because I caused altercations among the festival participants. I replied right away, saying that the allegations stated in the letter were false. I told him clearly that I refused to be intimidated by his letter, and I assured him I would attend the festival as it was a community festival and would be held in a public venue. On July 23, 2007, while I was eating lunch with friends in one of the Eritrean restaurants located on Bloor Street near Ossington, I found that the tire of my car had been pierced with a knife (Berhane, 2007 August, 15). 
I shared the letter I received from the chair of the festival organizing committee with PEN Canada, the Canadian Journalists for Free Expression (CJFE) and the Toronto police.

PEN Canada immediately sent a letter (see Appendix 9) via courier to the organizing committee which is located at the same address as the Eritrean Consulate, asking them to retract their intention of excluding my participation, but the office refused to accept the letter. PEN Canada sent the same letter again by another courier, but the consulate refused to accept it, saying the chairperson had resigned from his post. PEN Canada thought this was a ridiculous excuse and expressed their strong opposition to the action of the organizing committee in their letter. The letter stated, "PEN Canada believes that freedom of expression and freedom of the press to observe, record and comment on public events are cornerstones of the free and democratic society that Canada is. An event in a public park is, by its very nature, a public event and that means it must be open to the media to attend and cover it. Any attempt to prevent or restrict media coverage to only selected journalists or news organizations is wrong and should be resisted by everyone who believes in democracy” (see Appendix 9).

I attended the Eritrean Festival 2007 in Toronto, which was held in Earl's Court on August 4. Once I started taking pictures and interviewing people about the event, the chairman whom the organizing committee claimed had resigned from his post, came with his group and asked me to leave. I refused. They called the police and told the police a fabricated story. After I had stayed in the festival field for an hour, the two officers came to where I was standing. As soon as they heard my side of the story, they assured me that I had the right to attend the public event and they left, 
shaking my hand (Berhane, 2007 September: 4). Then, to the disappointment of the Eritrean Consulate, I stayed until the end of the festival.

\subsubsection{Vandalism}

One of the major problems I faced as a journalist in Toronto were acts of vandalism. The newspaper I was publishing and the car I was driving became a target of vandals. Copies of my newspaper - Meftih — were dumped in the garbage after they were distributed at several locations: Eritrean stores, restaurants and community centers. This happened a number of times during the first year of the publication of the newspaper in 2004 \& 2005 (Meftih, 2005 Oct: 15).

My car was also vandalized twice after I published my usual critical columns in my newspaper and after I wrote comments on my blog. I testified in the House of Commons at the Subcommittee on International Human Rights of the Standing Committee on Foreign Affairs and International Development in February 2012. “The tires of my car were also pierced with a knife on July 23, 2007 after I had been publishing Meftih since 2004. I repeatedly criticized the Eritrean government representative in Canada in Meftih for 'manipulating the community festival to carry out the political agenda of the Eritrean regime political agenda and to raise funds.' The windows of my car were smashed on January 3, 2008 after I criticized the Eritrean government 'for converting the country into a huge prison camp’ on my blog, asmarino.com (Subcommittee on International Human Rights of the Standing Committee on Foreign Affairs and International Development, 2012). 


\subsubsection{Social Isolation}

“Eritrea’s leadership uses its security and political party machinery, including its official representations abroad, to intimidate and control the population. As a result, Eritreans are afraid to join certain political or religious organizations in the diaspora or to freely express their opinions regarding the situation in their country” (Commission of Inquiry on Human Rights in Eritrea, 2015: 101). The Eritrean Consulate uses different tactics to isolate its critics from the community pool. It advises and intimidates community members not to do business or attend wedding parties, funeral ceremonies or any festivities held by the individuals who oppose the Eritrean government. I have been a target of such a smear campaign of the consulate since 2004. Most Eritrean Canadian business owners who used to advertise in my newspaper were told to withdraw their ads from Meftih. Many did so out of fear. About five business owners were forced to retract their ads even though they had paid for the ads six months in advance. Almost all of them mentioned that they had canceled their ads because they didn't want to create problems with the consulate.

The other tactic the consulate uses to make its critics hated by the community is character assassination. I have been a target of such defamation for a decade. I was labeled a traitor, a CIA agent and a collaborator of the Ethiopian regime. At the end of 2008, I published that the Eritrean Community Association of Ontario (ECAO) is exploited by the consulate. From July 2009 to February 2010, I wrote an investigative report on the corruption of one of the employees of the Eritrean Consulate in Toronto who was involved in the organization of the Eritrean Festival since 2001 (Berhane, 2010: 1-12). Particularly after I made these consecutive remarks, I was bombarded with calls from unknown telephone numbers, and I heard insulting and intimidating voices. To 
consolidate its attack, the consulate started a new publication called Meseret by the name of the ECAO to respond to the criticisms presented in Meftih. In the first issue of Meseret in January 2009, the chairman of ECAO published a defaming story about me. He accused me of having a hidden agenda to cause the Eritrean community to disintegrate and dismantle its unity (Tewelde, 2009: 3-6). He published his defamatory articles in five consecutive issues of Meseret, but never tackled the long report I presented in Meftih where I criticized the consulate.

\subsubsection{Family Reunification}

"These reprisals by the Government have a disparate impact on women, particularly wives, who are often left destitute with children when their husbands or male family members escape or desert the national service” (Commission of Inquiry on Human Rights in Eritrea, 2015: 97). After I fled Eritrea, my wife was watched closely by the security agents of the country. Her telephone was tapped; her movements were scrutinized. As I wrote in the Literary Review of Canada, my wife took most of the heat. "She was summoned to the police station several times between 2002 and 2007 to be interrogated about my activities in Canada. When I wrote in my blog about the declining quality of education due to dissatisfied teachers and poor administration, she was summoned and asked if she was the primary source for the article. They made that assumption because she is a teacher. On several occasions, she was asked to provide a list of my close friends and associates with whom I had been in contact before I fled the country" (Berhane, 2012). It was a mental torture for all of us.

My wife and children were not allowed to leave the country. Since my wife was not able to move freely and all her telephone conversations were tapped by security agents, we had to be creative in 
the way we communicated. We used several codes to arrange her escape with the children. We used particular words to describe specific tasks. Sometimes we discussed the escape as a school project by using phones that didn't belong to her. Once we agreed on the plan, I was so worried in executing it. The shoot-to-kill policy and the unstable and selfish behavior of the smugglers' minds disturbed me. I turned down several smugglers until I found the right one who passed my test. There were nights that I never slept at all due to the disturbing ideas floating in my mind. Finally, "at the end of 2009, thanks to a well-orchestrated operation, I managed to smuggle my wife and children into Sudan; they joined me in Canada in May 2010” (Berhane, 2012). It took me eight years for me to reunite with my wife and three children who were six months, four and seven years old when I left. I have lost a huge chunk of their lives, and I always feel guilty about that.

The overall activities of the consulate-intimidation, vandalism, social isolation and all kinds of obstacles to prevent me from reuniting with my family, have had a great impact in the process of my resettlement. It has doubled the length of my journey and slowed down my integration in Canada. 


\section{Conclusion and Recommendations}

An extraordinary number of migrants from developing countries arrived with the introduction to an official policy of multiculturalism in Canada $(\mathrm{Ku}, 2010)$. Since then, Canada has become the home for thousands of Eritrean refugees who were forced to leave their country of origin because of war, colonialism and political instability. During the thirty-year armed struggle for Eritrea's independence (1961-1991), more than half a million people fled to neighboring countries (Hepner, 2003, 2008). The flow of migration hasn't stopped even after the independence in 1991, has intensified particularly since 2001. Every month, more than 4,000 Eritreans seek refuge in Ethiopia or Sudan (UNHCR, 2014). That makes Eritrea one of the leading refugee-producing countries (Human Rights Watch, 2009; UNHCR, 2014).

The contextual review reveals that Eritrean refugees faced a number of obstacles during their settlement process in Canada. Like many African immigrants, their settlement path included facing hurdles like the language barrier, financial challenges, discrimination and lack of employment. However, to make matters worse, unlike other African immigrants, their journey to a new life in Canada was impacted negatively because of the coercive transnational governance of their home country.

The only office that represents the Eritrean government in Canada which is the Eritrean Consulate in Toronto uses extortion, threats of violence and other illegal means to collect $2 \%$ income taxes from Eritrean Canadians (Monitoring Group, 2012). Most are forced to pay because the government will not honour their request to grant them their educational documents, birth 
certificates, copies of marriage certificates or any other vital documents that can assist them to obtain permanent resident status in Canada. In extreme cases, some are forced to pay the money to renew the business licenses of their parents who live in Eritrea. If they refuse to pay the $2 \%$ income tax, the business licenses of their parents will not be renewed. Even those who do not request any documents and refuse to pay the $2 \%$ income tax are approached and intimidated by agents of the regime. These immigrants are warned to do it for the sake of their families who live back in Eritrea.

A sample of eleven people were recruited for this research beside the researcher's personal experience. They included eight Eritrean refugees who arrived in Canada in the last 20 years, an activist and two law enforcement agents. The victims were selected because they had applied to the Eritrean Consulate for various services. The activist was selected due to his active involvement in advocating against the violation of Eritrean human rights. And the law enforcement agents were approached due to the relevance of their work. They shared their experiences and observations in the open-ended interviews that the researcher conducted.

The findings clearly confirm the issues discussed in the literature. The Eritrean Consulate in Toronto creates insurmountable hurdles for Eritrean refugees in the initial stages of their settlement by instilling fear, dangling its consular services for a payment of $2 \%$ income tax and drying up the financial resources of Eritrean refugees. The participants shared the terrible journey they experienced that made their transition to a new life very hard and rocky. 
One of the impediments that all participants experienced during their settlement process was fear. The fear instilled by the Eritrean Consulate silenced the refugees' critical voices because the consulate spied upon their activities and punished family members of any exiled person who spoke against the Eritrean government. Despite the full protection granted by the Canadian government, participants lived under constant fear of the regime that was trying to govern them from afar. Five of the participants didn't seek help or file their complaints to Canadian law enforcement agents due to the fear of retaliation to their loved ones by the Eritrean regime. They didn't want to witness the overt or hidden threats they faced from the Eritrean consulate. One of the three participants who complained to the police found their response patronizing and not supportive, and that discouraged him from approaching the police again. Nevertheless, the Canadian law enforcement agents believed that they would need the relentless support of the victims to push cases forward and put an end to the constant fear that refugees, permanent resident or citizens of Eritrean origin experience. Their vague response to the pointed out issues and reluctance to talk on details on how they can protect the victims might cripple the intention of their good will and still discourage victims to come forward.

The other challenges that were investigated was:

1. the hindrance to family reunification,

2. the denial of legal and educational documents from Eritrea,

3. the psychological trauma and

4. financial burden.

Most participants were separated from their loved ones for a number of years. For the sake of their families and their loved ones who lived under the grip of the Eritrean regime, three of the 
participants who felt squeezed between a rock and a hard place, fulfilled the coercive demands of the consulate. They paid 2\% of their annual income and donated money to military defence so as to get exit visas for their family and secure their educational documents from Eritrea.

Two of the participants and the researcher took another route to reunite with their families since they believed that paying the Eritrean consulate wouldn't guarantee exit visas for their loved ones. They took the greatest risk by dealing with human smugglers to bring their families out of a country that practices a shoot-to-kill policy if anyone tries to cross the border without a permit. They were forced to pay thousands of dollars to smugglers and they put themselves in terrible psychological turmoil for placing their loved ones in the line of danger.

One of the participants was denied her educational documents because she refused to fulfill the demands of the consulate, that is, sign a regret form and pay $2 \%$ of her annual income. She paid a high price for that. Her study was delayed by four years.

The last obstacle mentioned in the findings was the issue of financial burden. Like any newcomer, most participants had a rough start due to lack of employment and adequate income. While they were struggling to make ends meet, they received demands to pay a percentage of their annual income for basic consular services. They were also forced to contribute a one-time $\$ 300-\$ 500$ for the development of the Eritrean defence force. Even the people who lived under the social welfare were demanded to pay and donate. They had to send money to support their families and pay smugglers to secure the escape of their loved ones who didn't receive exit visas to leave Eritrea. 
This heavy financial burden hindered their settlement from the very start and it took them a long while to fully recover financially.

The findings reveal that the Eritrean Consulate is the cause of the rough transition and integration process of Eritrean refugees in Canada. The consulate impacts the settlement process of refugees negatively by applying coercive transnational governance and undermining Canadian law. It threatens refugees who criticize the Eritrean regime, makes them not only to donate money but forces them to pay $2 \%$ of their annual income for irrelevant services. To counteract the activities of the refugees, the regime toys with the refugees' loved ones who live in Eritrea. That gives the Eritrean Consulate an extremely high degree of leverage to force refugees, permanent residents or citizens of Eritrean origin to abide by its rules. This undermines Canadian sovereignty as the consulate seems to have upper hand in dictating the Canadian citizens of Eritrean origin by overpassing the safety net of Canadian value. The consulate uses the facade of a legal office to perform its illegal activities and intrude to the life of Canadian.

It is the absence of such mechanisms that can protect refugees from such coercive activities exacerbates refugees' situations. Their settlement process and integration is slowed down; their savings are drained; and they become victims of illicit activities of the Eritrean Consulate.

\subsection{Recommendations}

Seven recommendations result from this study to alleviate the challenges of Eritrean refugees and secure Canadian sovereignty. 
1. Create a specific unit or at least a contact person that allows refugees to file their complaints easily whenever they are threatened, receive demands to pay money or ordered to become involved in activities against their will by the government of their home country or its representatives.

2. The Canadian government has to address the big concerns of Canadian citizens of Eritrean origin with the Eritrean government on higher level and end the practice of the regime that undermines Canadian sovereignty and threats the citizens’ safety.

3. Design a specific protection such as witness or victim protection, and non-disclosure of victims identity, to encourage victims come forward

4. Educate newcomers about their rights and duties in Canada, and how the law enforcement agents operate to protect them.

5. Fund legal clinics and community services or organizations to promote access to justice

6. Give extensive training and awareness to law enforcement agents about the complexity of challenges refugees face from their countries of origin as soon as they have landed in Canada. For example, the dictatorial regimes use their consulate offices or individuals to rule their citizens who live in exile.

7. Promote and fund research on coercive transnational governance and experiences of certain groups of nationalities. 


\section{Appendices}

\section{Appendix 1}

\section{Data Collection}

\section{Interview Questions to Eritrean Refugees}

1. How do you describe your settlement experience in Canada?

2. How do you explain the role of Eritrean consulate in the life of Eritrean Canadians?

3. What kind of services have you requested from the Eritrean Consulate?

4. What is your personal experience with the Eritrean consulate?

5. Do you have any concern on the way the Eritrean consulate office or representatives do their business?

6. Have you ever approached the Canadian law enforcement authorities in regards to your safety or any other activities of the Eritrean consulate?

7. What do you want to be done to alleviate the challenges of Eritrean immigrants in Canada?

\section{Interview Questions to Human Right activists:}

1. How do you explain the role of Eritrean consulate in the life of Eritrean Canadians?

2. What are the main complaints that you hear from Eritrean migrants?

3. What kind of challenges do Eritrean migrants face from the Eritrean consulate?

4. How effective is the role of Canadian law enforcement authorities in protecting Eritrean migrants from any illegal activities of the Eritrean consulate?

5. What do you want to be done to alleviate the challenges of Eritrean immigrants in Canada?

\section{Interview Questions to Law Enforcement Authorities}

1. What is the general procedure police follow to address the problem s such as intimidation, coercion or harassment from a government of another country?

2. What kind of complaints do you receive from Eritrean migrants in regards to fundraising, harassment or any illegal activities of Eritrean consulate?

3. How do you assist migrants who are forced to contribute money to the regime of their home country?

4. How do you protect newcomers that are harassed by the government of their home country via their diplomats?

5. How informed are police about the transnational nature of community politics and the controversial fundraising activities?

6. What kind of coordination do local police have with RCMP or CSIS? 


\section{Appendix 2}

\section{2\% Tax Form with Defence Contribution (Tigrigna)}

Annex 3.1.c

Two per cent form with defence contribution ${ }^{1}$

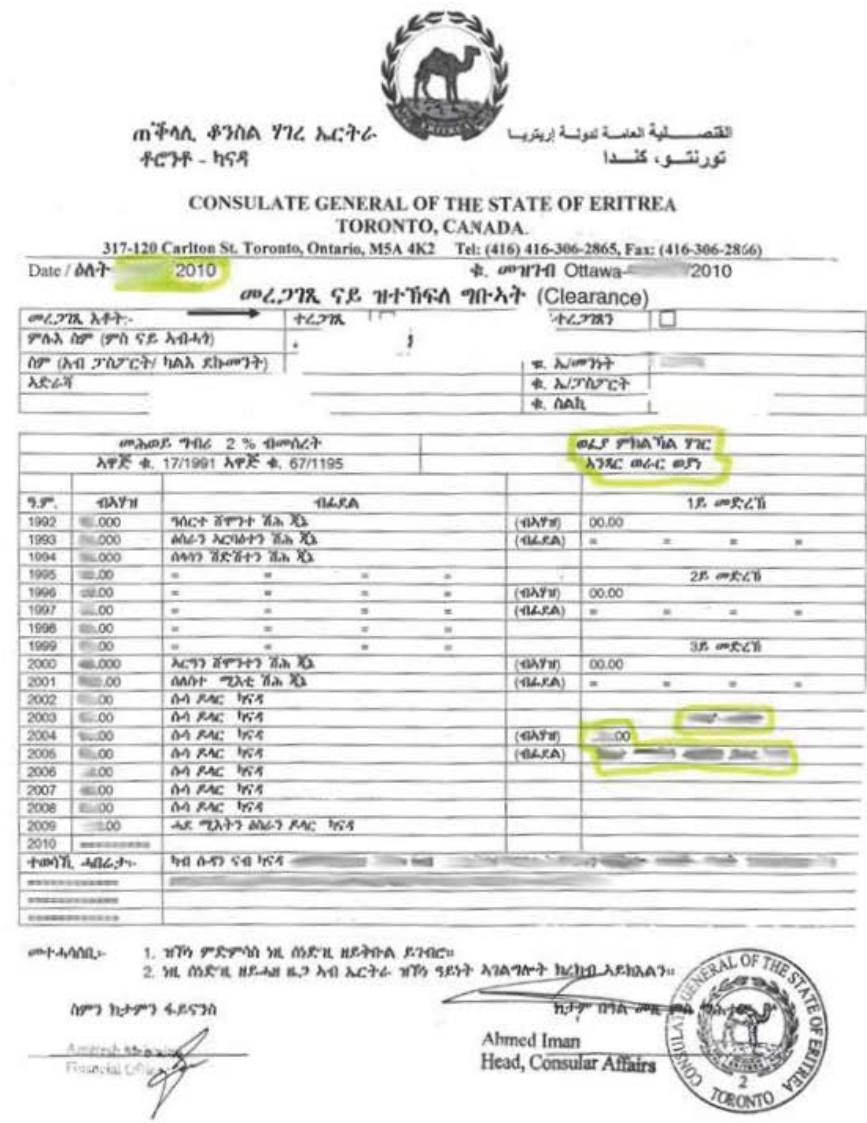

1 Document received from Eritrean Community Center (C anada); via third party. 


\section{2\% Tax Form with Defence Contribution (English translation) \\ LOGO}

CONSULATE GENERAL OF THE STATE OF ERITREA

TORONTO, CANADA

\section{2\% TAX FORM}

317-120 Carlton St. Toronto, Ontario, M5A 4K2 tel: (416)306-2865 Fax: 416-306-2866

Date:

File Number:

\section{CLEARANCE}

Proof of Income

Full Name along with grandfather's:

Name as in passport and other document Eritrean ID Card: 136616

Address:

Phone Number:

Recovery tax 2\% according to Proc. 17/1991, Proc. 67/1195

\begin{tabular}{|r|l|l|l|}
\hline Year & $\begin{array}{c}\text { In Numbers } \\
\text { 2\% }\end{array}$ & $\begin{array}{c}\text { In Alphabets } \\
\text { taxtax }\end{array}$ & $\begin{array}{l}\text { Donation to national Defense } \\
\text { against Ethiopian invasion }\end{array}$ \\
\hline 1992 & & & $1^{\text {st }}$ Stage 00.00 \\
\hline 1993 & & & \\
\hline 1994 & & & \\
\hline 1995 & & & $2^{\text {nd }}$ Stage 00.00 \\
\hline 1996 & & & \\
\hline 1997 & & & \\
\hline 1998 & & & \\
\hline 1999 & & & \\
\hline 2000 & & & \\
\hline 2001 & & & \\
\hline 2002 & & & \\
\hline 2003 & & & \\
\hline 2004 & & & \\
\hline 2005 & & & \\
\hline
\end{tabular}




\begin{tabular}{|l|l|l|l|}
\hline 2006 & & & \\
\hline 2007 & & & \\
\hline 2008 & & & \\
\hline 2009 & & & For Defense (donation) \\
\hline 2010 & & & \\
\hline & & & \\
\hline
\end{tabular}

Additional information: He came to Canada from Sudan in 28/02/2009. We referred to clearance number 130/2001, given by Eritrean embassy in Khartoum showing the duties he paid in Sudan from 1992-18/06/200.

Notification :-

1. We notify you any kind of erasure is not acceptable.

2. We inform you beforehand that no services will be rendered for a person who enters without this document.

Name AND Signature of the Finance

Amaresh Mebrahtu

Financial Officer
Name and signature of the Head

Ahmed Iman, Head of Consular Affairs

Stamp (Office of the Embassy of Eritrea)

Source: UN Monitoring Group on Eritrea \& Somalia 


\section{Appendix 3}

\section{'Regret Form' (Tigrigna)}

Annex 3.1.b

Immigration and Citizenship Services request form

L $B 4 / 4.2$

ECQ 00 .

1. $g^{0} \wedge x h \varphi^{\circ}$

2.

3. ODI\&A

5. $\$ 86 \mathrm{hC}$

6. ก\%० $\lambda 2$

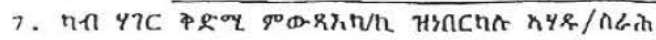

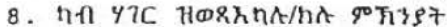

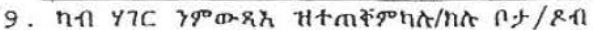

10. Horkinthe ont

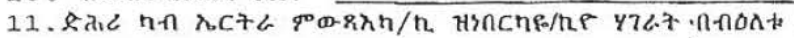

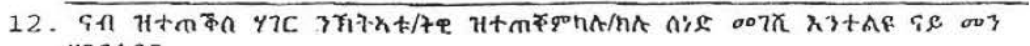
YาC' $ค$ ?

13. का ז

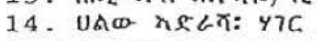

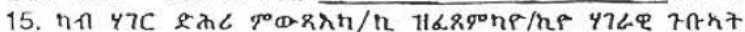

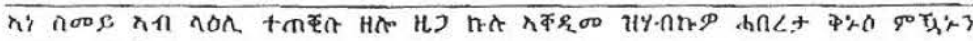

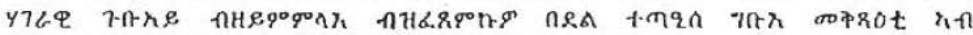

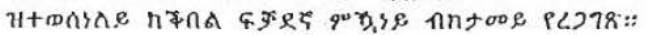

$n \rightarrow 4^{\circ}$

ont

3n9A OOH HFAnt

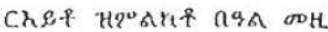

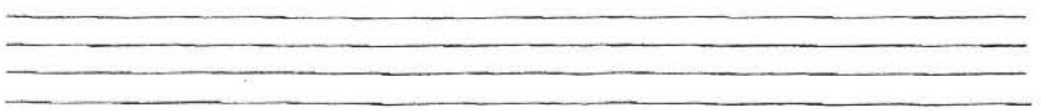

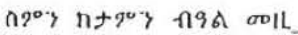
$b \wedge 7$

$\$ 3 \cap \wedge 920 / 8: 47 C$ $n+{ }^{4}$

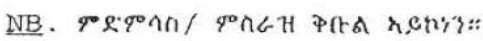




\section{'Regret Form' (English) Immigration \& Citizenship Services Request Form}

\section{Immigration and Citizenship Services Request Form}
Full Name
Gender
Full Name as shown in Passport
Village of origin
4. Date of Birth
5. Eritrean ID No.
Issued at
6. Mother's Name
7. Unit/Work you had before you left the country
8. Reason you left the country
9. Place/Border used to leave the country
10. Date you left
11. Countries you have been after you left the country and the dates you entered these countries
12. Whose country entry documents did you use to enter these countries?
13. Your job in the current country of residence
14. Current address: Country
City
15. National obligations fulfilled after you left the country

I, whose name is written above, confirm that previously given personal information is true; and that I regret having committed an offence by not completing the national service and am ready to accept appropriate punishment in due course. 


\section{Appendix 4}

\section{Power of Attorney Form in Tigrigna}

Annex 3.1.a

Power of attorney form and certified translation ${ }^{1}$

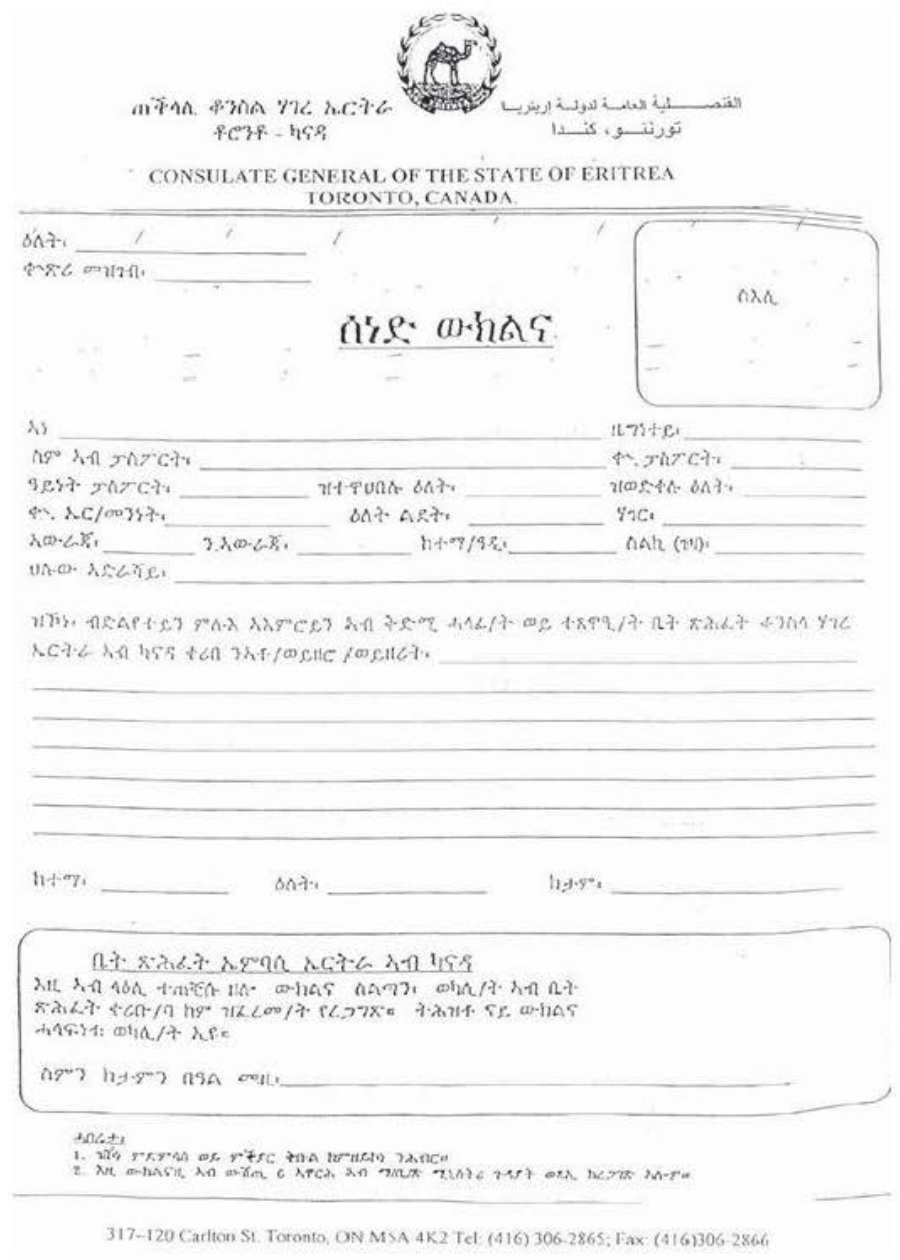

1 Docum ent translated provided by E1sa Chylum, Hum an Rights activist, phone and e-mail communications, 5 June 2012.

$12-38313$

Source: UN Monitoring Group on Eritrea \& Somalia 


\section{Power of Attorney Form in English}

\section{Emblem of the State of Eritrea}

Consul General of the State of Eritrea

Toronto - Canada

(in Tigrinya and Arabic on either side)

Date

Document No.

Legal Representation Form

Photograph

I

Name on Passport

Nationality

Type of Passport

Passport No.

Eritrean ID No

Expiration Date

Province

Date of Birth

Country

Current Address

District

City/Village

Home Phone No.

Being of sound mind and in the presence of an official representative of the Consular of the State of

Eritrea in Canada, it is my desire to appoint

$\mathrm{Mr} / \mathrm{Mrs} / \mathrm{Miss}$

City

Date

Signature

Embassy of the State of Eritrea in Canada

The above mentioned has, with their signature, confirmed the legal representation of the representative.

The authority now remains with the representative.

Name and Signature of Officer 


\section{Appendix 5}

\section{Tax and Duties payment receipt}

Annex 3.1.d

Tax and duties paym ent receipt

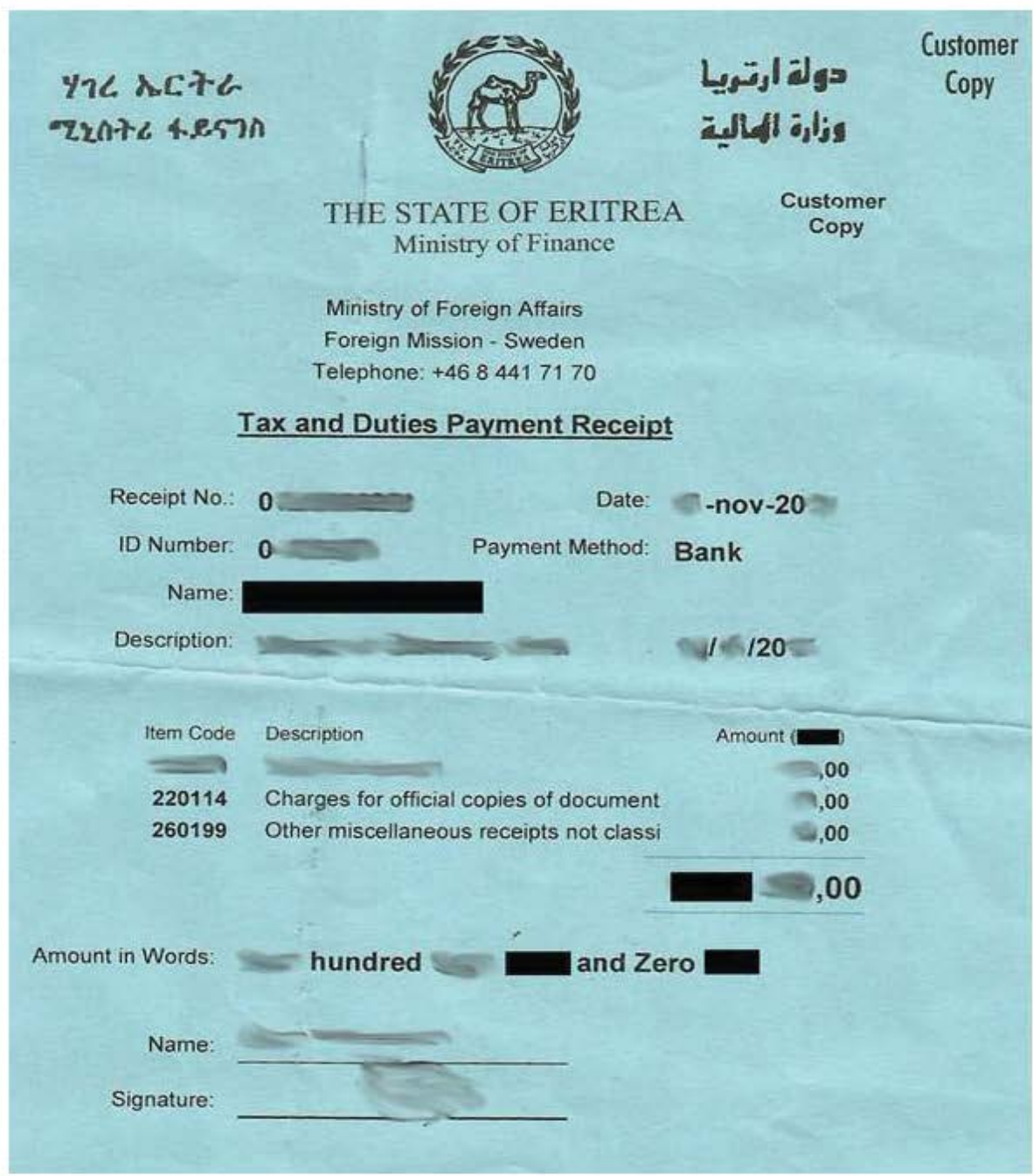

Source: UN Monitoring Group on Eritrea \& Somalia 


\section{Tax and Duties payment receipt}

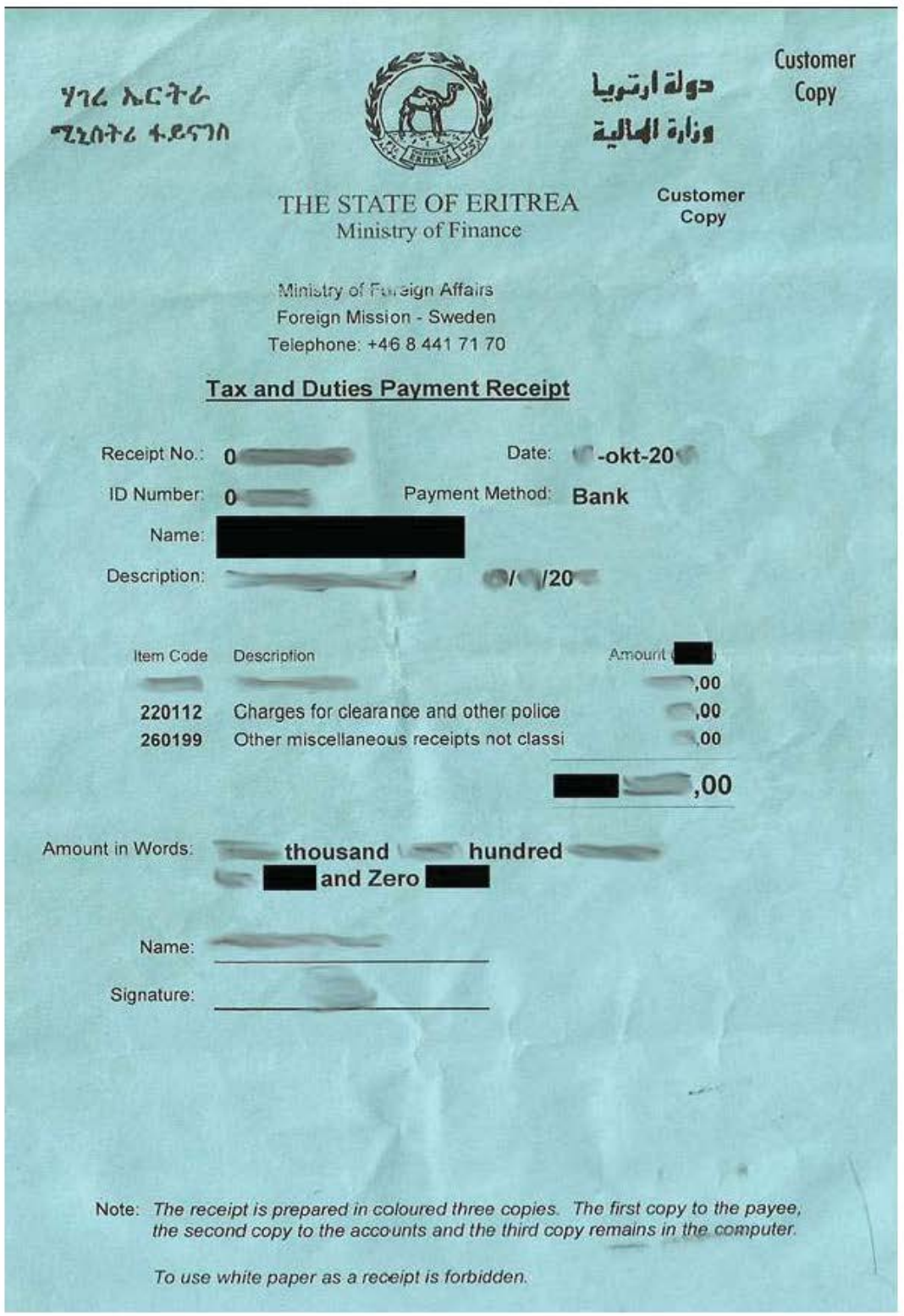

Source: UN Monitoring Group on Eritrea \& Somalia 


\section{Appendix 6}

\section{Excellent, But This Festival Needs Ground Breaking Maintenance}

Meftih 3.2 October 2006: Page 11

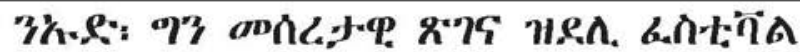

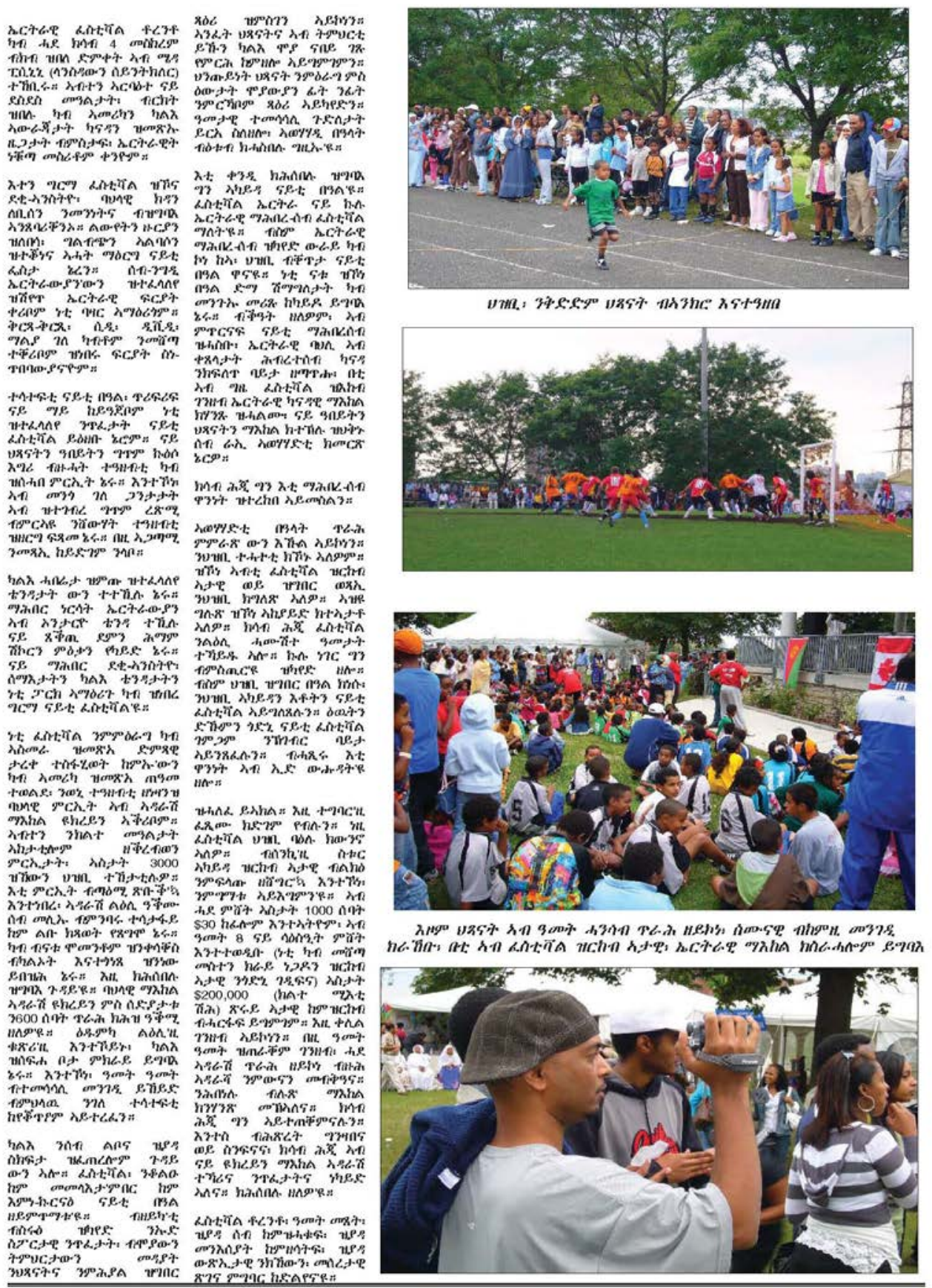




\section{Appendix 7}

Eritrean National
Holidays Organizing Committee
ONTARIO
ECC, 120 Carlton Street, Suite 309, Toronto, Ont. M5A 4K2
Phone: (416) 516-1246

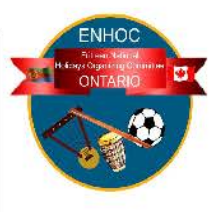

Temesgen Tirfe

Chair, Eritrean National Holidays Organizing Committee

120 Carlton Street, Suite 309

Toronto, Ontario, M5A 4K2

July19, 2007

Mr. Aaron Berhane

Meftih Enterprise

260 Adelaide St. East, Toronto, Ontario M5A 1N1

\section{Re: $\quad$ Toronto Eritrean Community Festival 2007}

Dear Mr. Berhane:

On behalf of the Eritrean National Holidays Organizing Committee (ENHOC) Toronto, I regretfully inform you that you are not invited to attend any venue of the forthcoming Toronto Eritrean Community Festival 2007. This decision is based on ENHOC's assessment of your conduct and involvement in altercation with festival participants during the Toronto Eritrean Community Festival 2006.

ENHOC will not be responsible for any consequences that may arise due to your attendance of any of the festival venues against the expressed wishes of the organizing committee.

If you need to discuss this matter further, please contact me.

Yours sincerely,

Temesgen Tirfe

C: $\quad$ Division 13 and Division 14 - Toronto Police Services. 


\section{Appendix 8}

Meftih 3.12 August 2007: Page 15

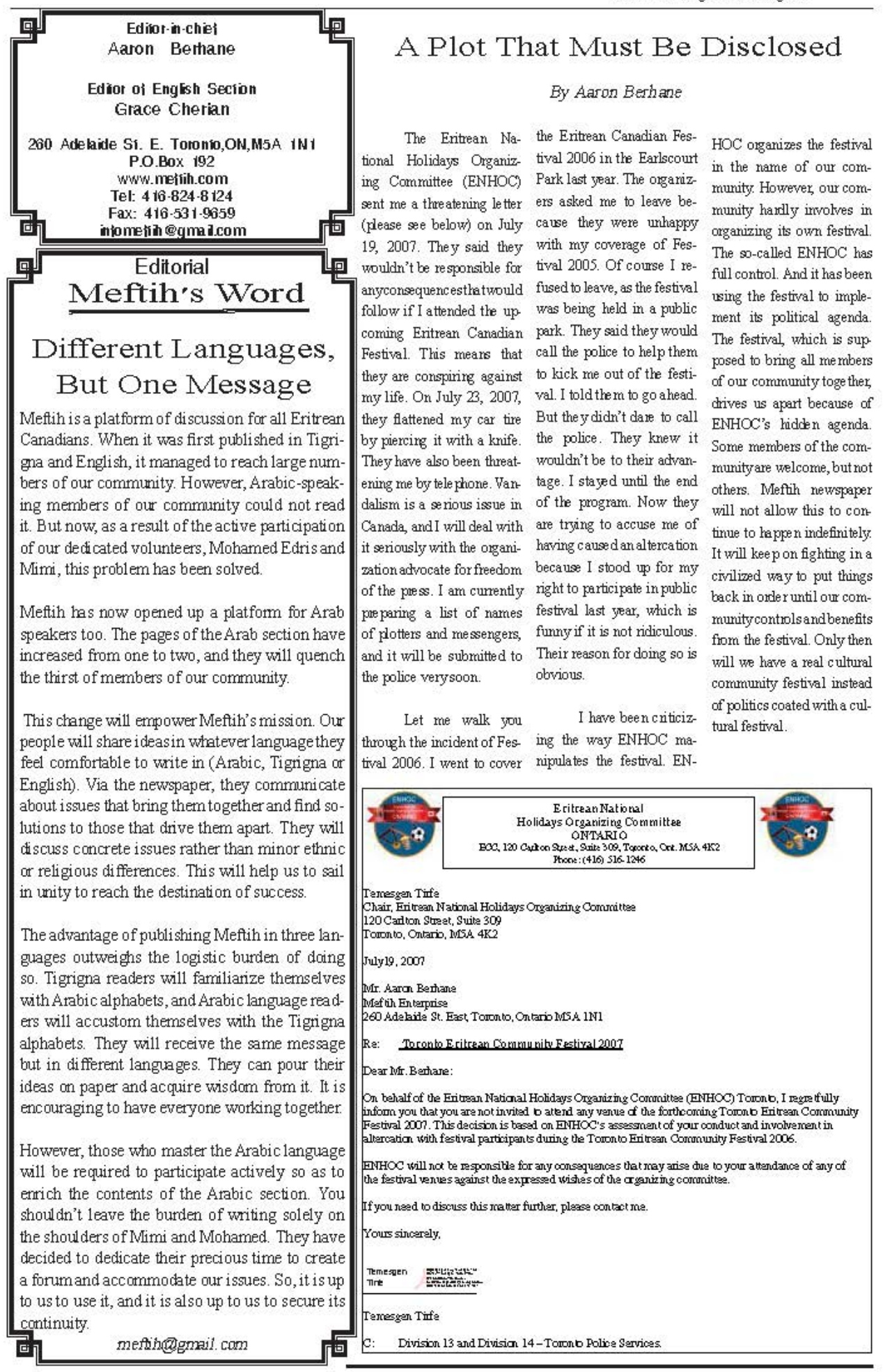




\section{Appendix 9}

\section{PEN Canada letter}

August 2, 2007

Temesgen Tirfe

Chair, Eritrean National Holidays Organizing Committee

120 Carlton Street, Suite 309

Toronto ON M5A 4K2

Dear Tesmegen Tirfe,

I am writing on behalf of PEN Canada, a centre of International PEN, the world literary and human rights association of writers with 144 centres around the world. PEN Canada works on behalf of everyone's right to freedom of expression, as guaranteed in Article 19 of the Universal Declaration of Human Rights and in other international treaties, and in Section 2(b) of the Canadian Charter of Rights and Freedoms.

We have read the letter your Organizing Committee sent recently to Aaron Berhane, the Editor-in-Chief and Publisher of Meftih newspaper in Toronto, informing him not to attend the upcoming Toronto Eritrean Community Festival. We have also spoken with Aaron Berhane, who is a valuable member of PEN Canada's Writers in Exile Network.

PEN Canada believes that freedom of expression and freedom of the press to observe, record and comment on public events are cornerstones of the free and democratic society that Canada is. An event in a public park is by its nature a public event and that means it must be open for the media to attend and cover. Any attempt to prevent or restrict media coverage to only selected journalists or news organizations is wrong and should be resisted by everyone who believes in democracy.

PEN Canada hopes that you will rescind your decision to forbid Aaron Berhane to attend your festival as a reporter for Meftih newspaper so that he may exercise his constitutional right as a Canadian citizen to hold opinions without interference and to report freely on this public event. As citizens of a democratic country, all Canadians also have the right to receive information expressed through newspapers such as Meftih.

I look forward to your response.

Best regards,

Isobel Harry

Executive Director 


\section{Appendix 10 \\ Festival 2007, An Event of Wisdom}

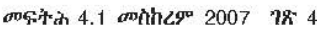

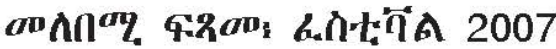

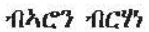
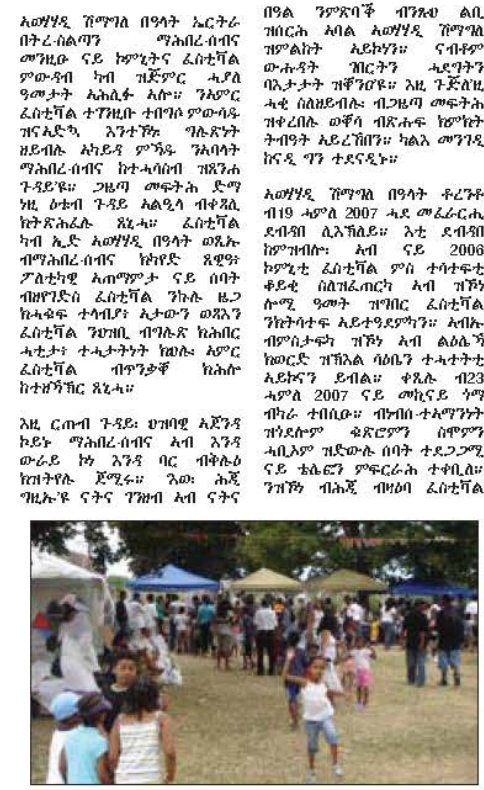

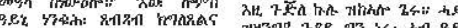

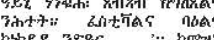

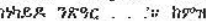

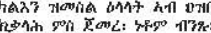

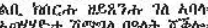

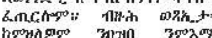

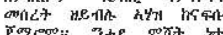

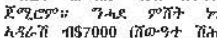

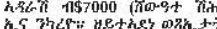

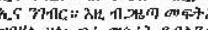

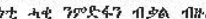

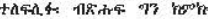

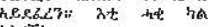
तोing:

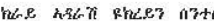
hoot hay

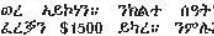

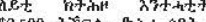
2., (1) nhe

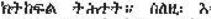

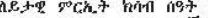

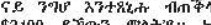
$\$ 3100$ g now

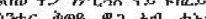
towaint:

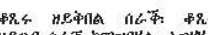

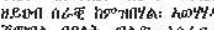

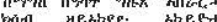

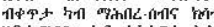

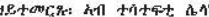

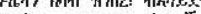

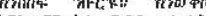

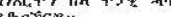

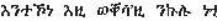

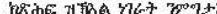

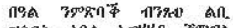

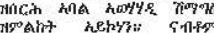

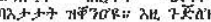

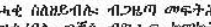
तnt

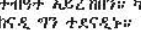

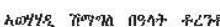

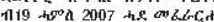

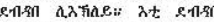

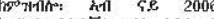

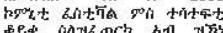
10\%

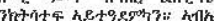

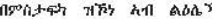

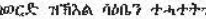

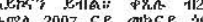

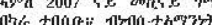

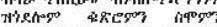
का

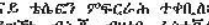
के a topes hese

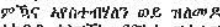

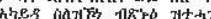

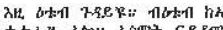

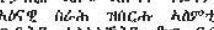
rain thent hio:

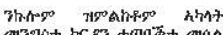

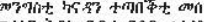

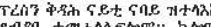

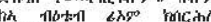

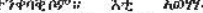

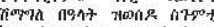

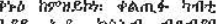

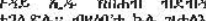
(x)

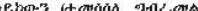

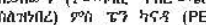

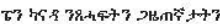

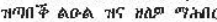

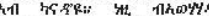
तुक्षणत tat noce ba nawn

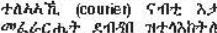
he ent?

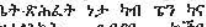

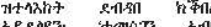

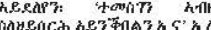

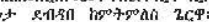

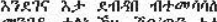
GA 7\% 11 e单F

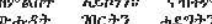

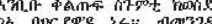

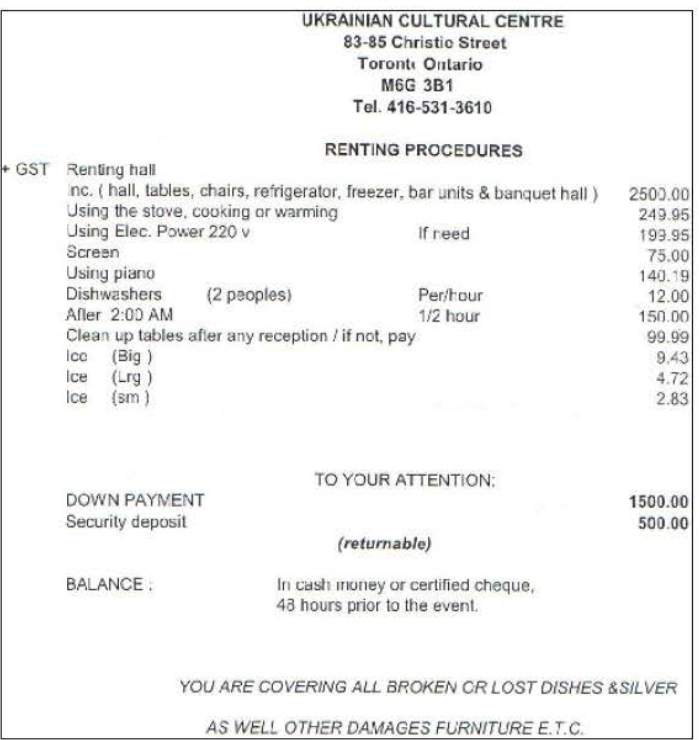

AS WELL OTHER DAMAGES FURNITURE E.T.C.

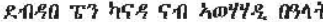

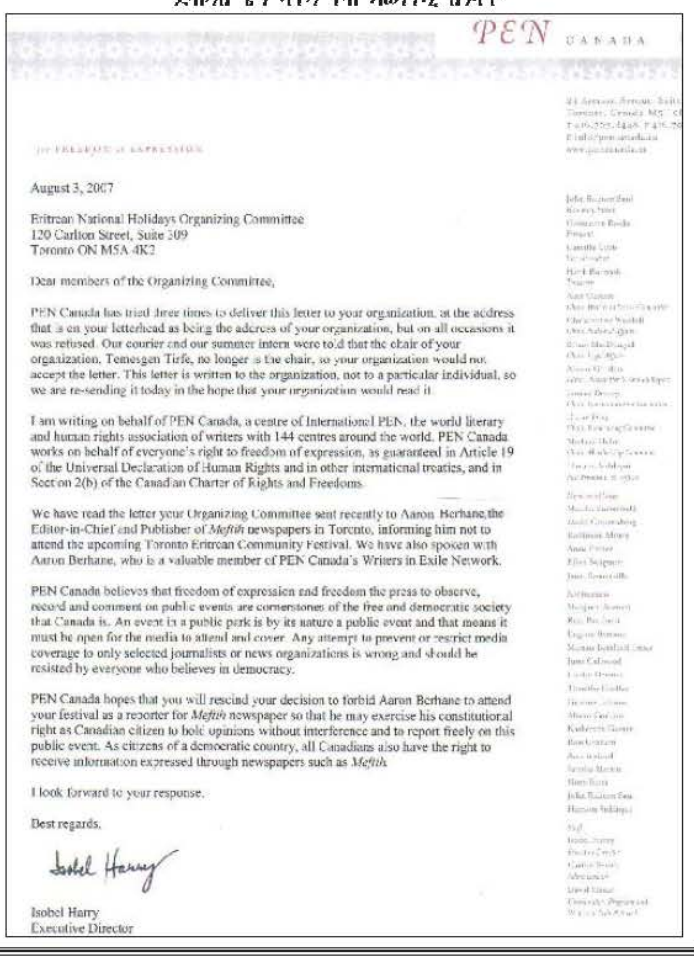




\section{Appendix 11}

\section{E.C.A.O. a Community looted by its guardian}
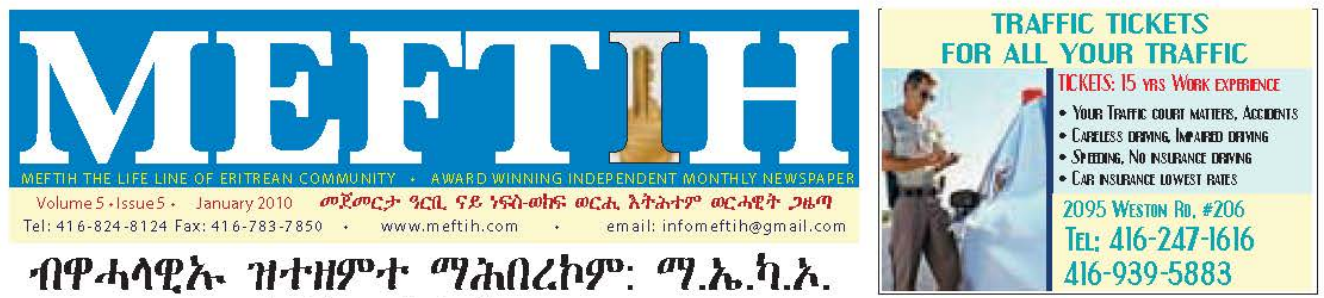

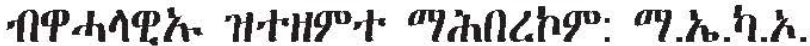

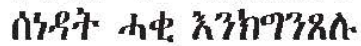

nhe? $n C^{4} \%$

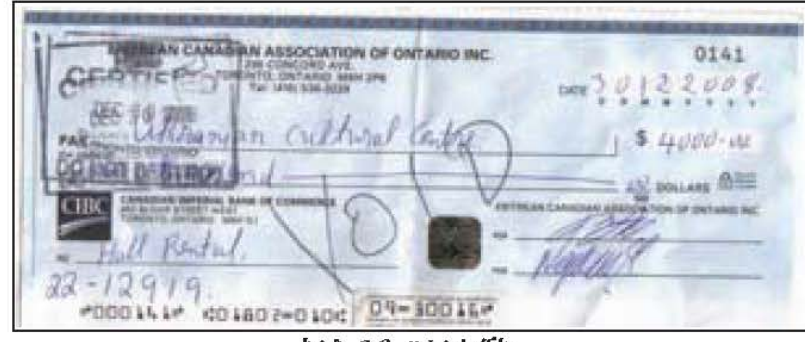

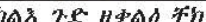

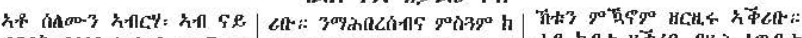

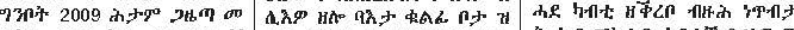

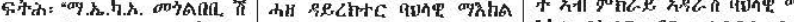

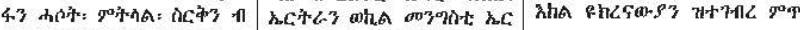

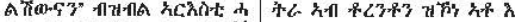

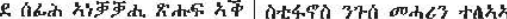

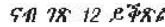

Cadn d, P:

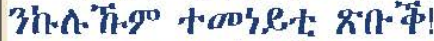

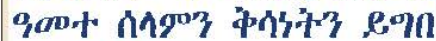

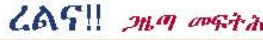

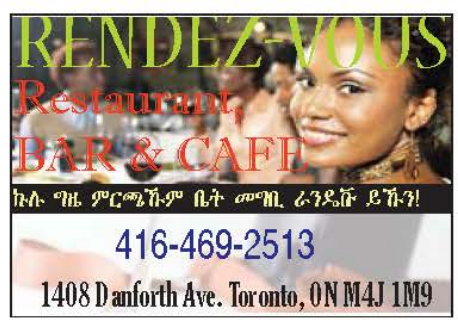

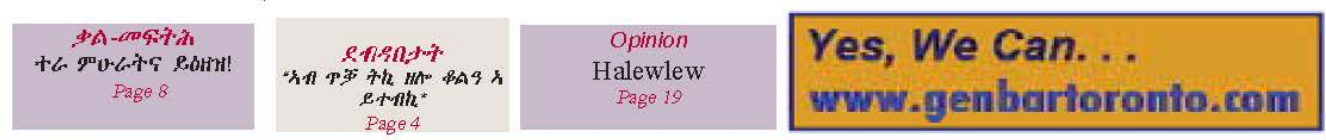

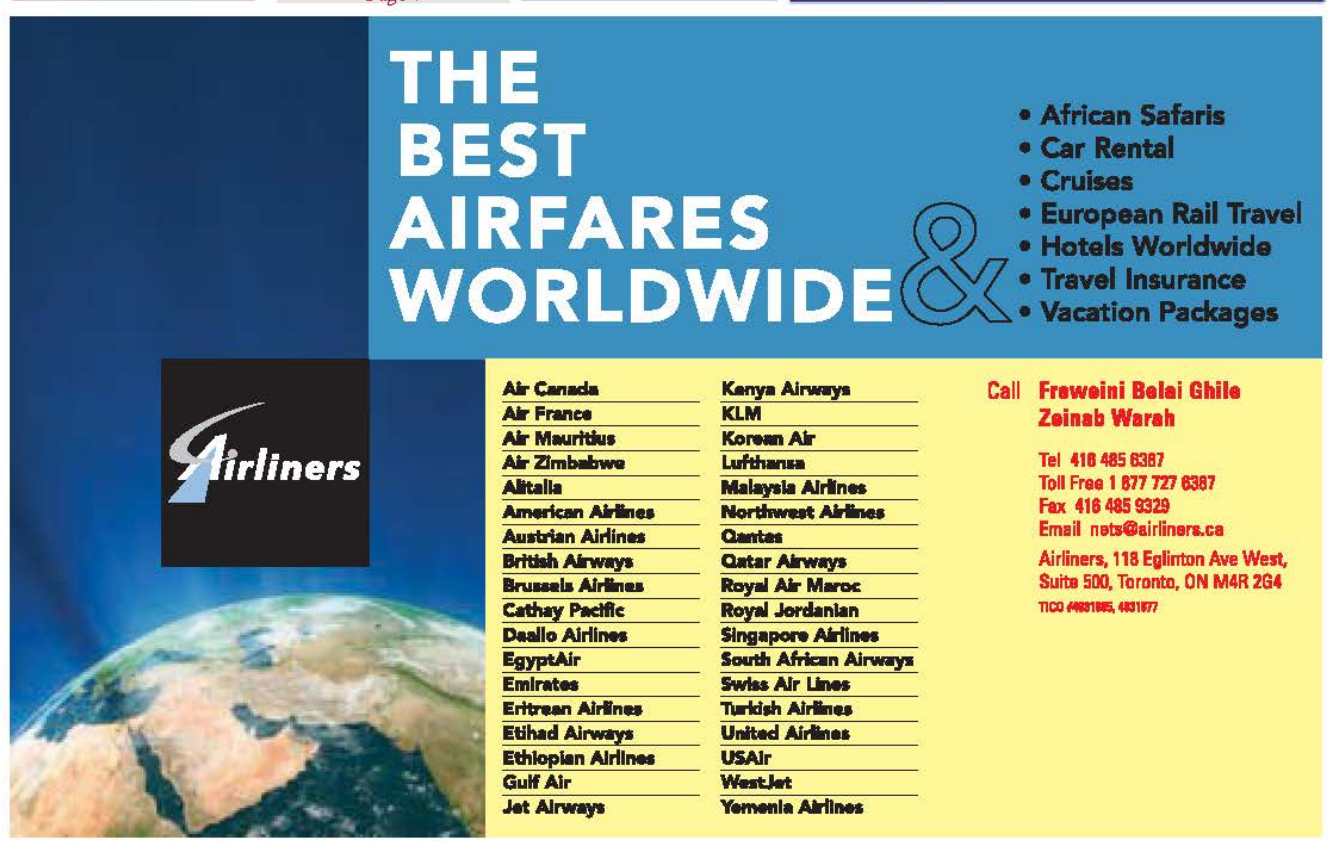




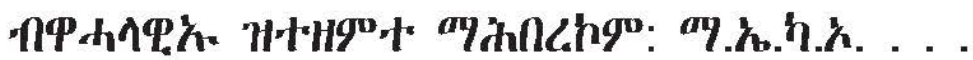

$\ln 1 \%$ WFA

F. $4.2: 1$

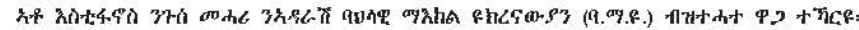

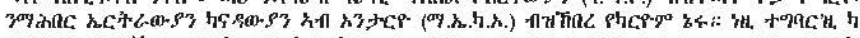

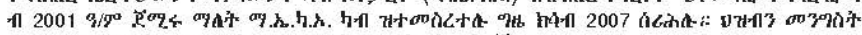

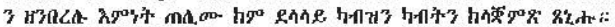

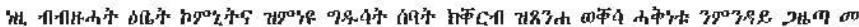

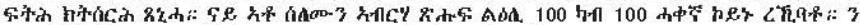

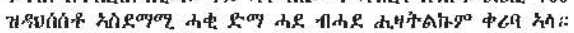

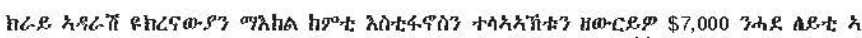

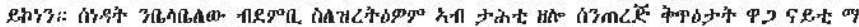
âha wohn: :

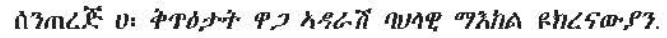

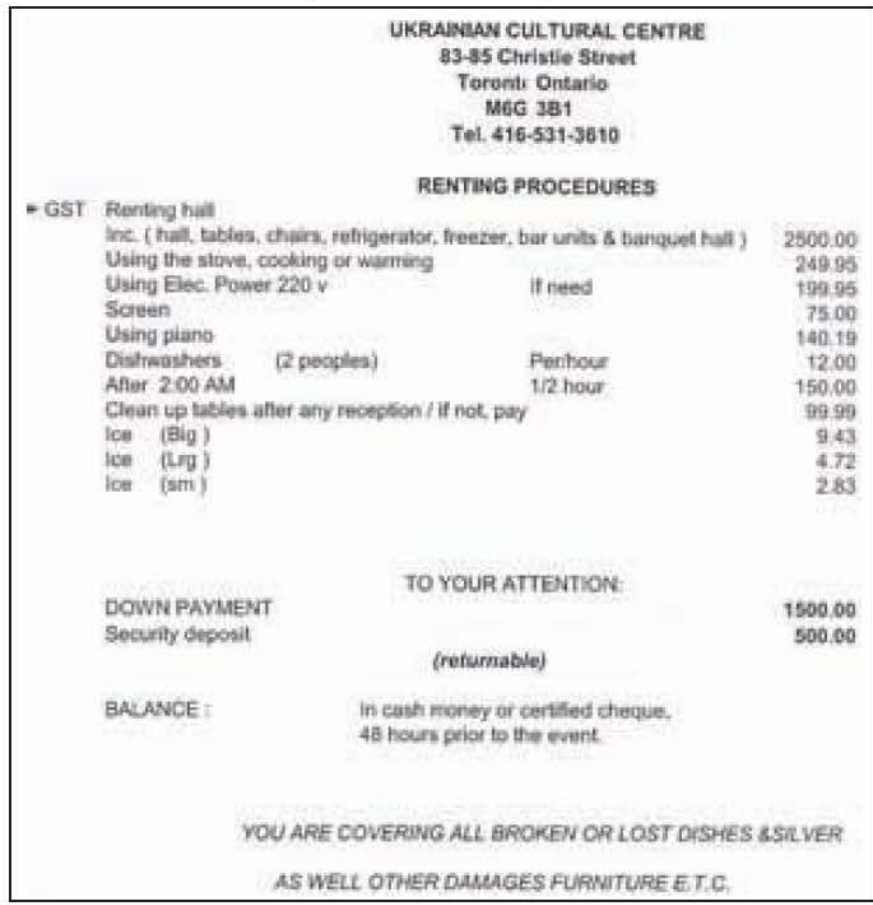

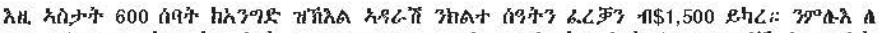

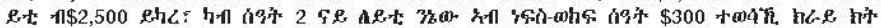

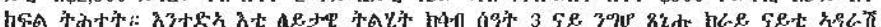

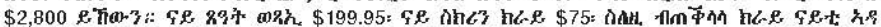

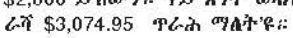

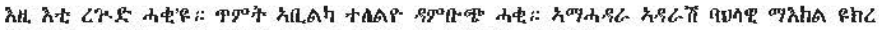

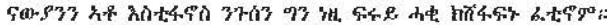

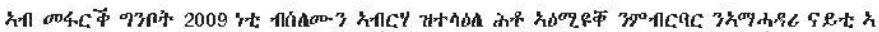

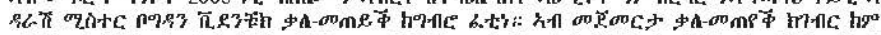

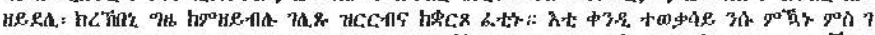

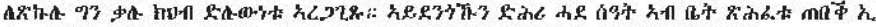

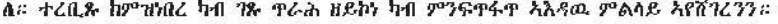

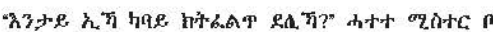
org?:

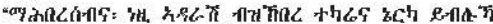

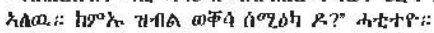

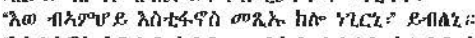

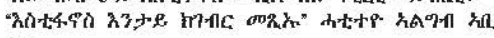
A: $:$

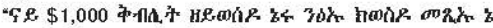

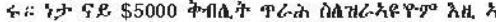

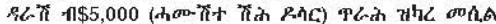

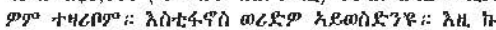

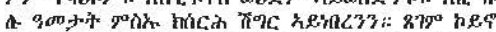

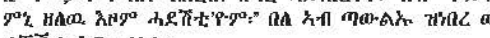

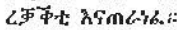

"YPST A

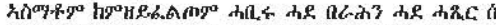

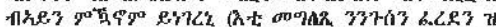

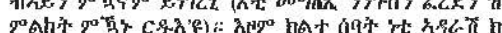

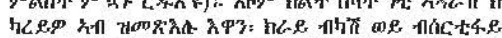

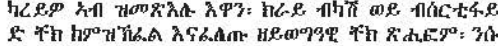

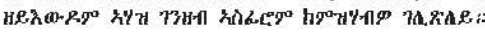

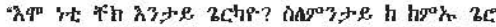
ga? ht: :

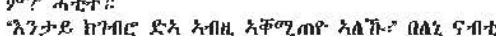

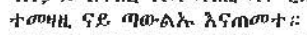

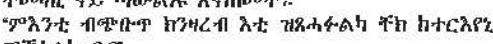
गัทुรดम 8?

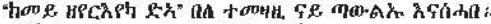
“侮

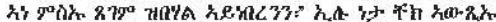

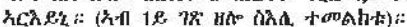

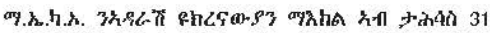

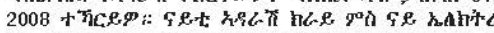

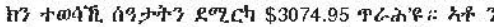
"fi twa

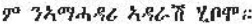

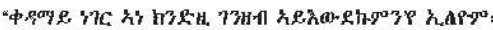

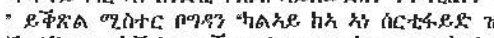

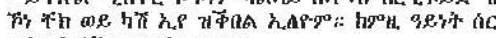
t4,es th PA? hap-ga::"

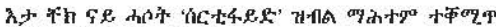

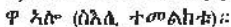

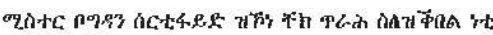

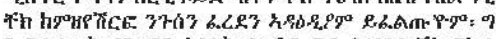

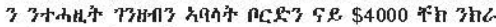

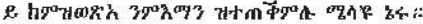

หी

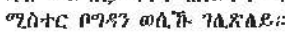

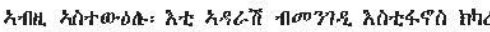
his $\$ 6000$ h4t $\$ 7000$ eh

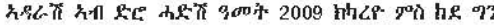

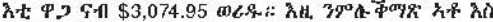

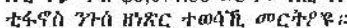

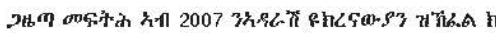

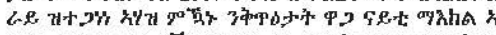

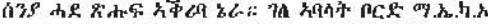

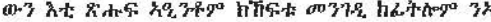

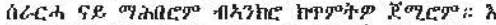

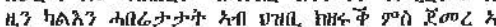
o nits. 


\section{Appendix 12}

\section{Congratulations, Meftih}

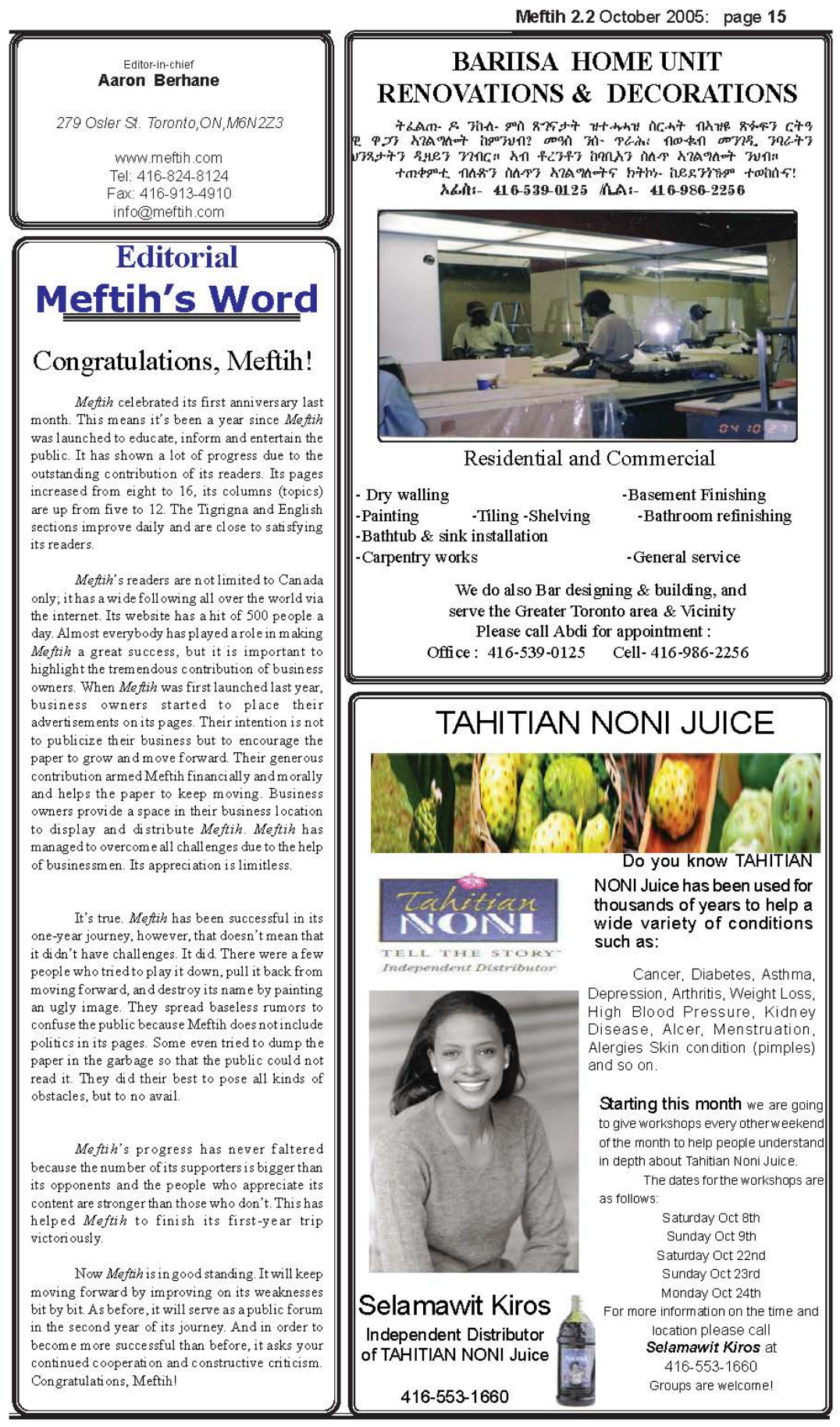




\section{References}

Al-Ali, N., Black, R., \& Koser, K. (2001). The limits to'transnationalism': Bosnian and Eritrean refugees in Europe as emerging transnational communities. Ethnic and racial studies, 24(4), 578-600.

Angrosino, M. (2007). Doing ethnographic and observational research. London: Sage Publications.

Bell, S. (2012, September 21). 'It is our right': Eritrea vows to continue taxing citizens in Canada despite warning from Ottawa. Retrieved September 20, 2015, from http://news.nationalpost.com/news/canada/it-is-our-right-eritrea-vows-to-continuetaxing-citizens-in-canada-despite-warning-from-ottawa

Bell, S. (2013, May 29). Canada expelling Eritrean diplomat for using consulate to shake down citizens for 'national defence’. National Post. Retrieved August 9, 2015 from http://news.nationalpost.com/2013/05/29/canada-expelling-eritrean-diplomat-for-usingconsulate-to-shake-down-citizens-for-national-defence/

Bengali, S. (2009). Eritrea: Africa’s version of North Korea?'. The Christian Science Monitor, 10.

Berhane, A. (2005, October). Congratulations, Meftih. Meftih, p. 15.

Berhane, A. (2006, October 1). Excellent, But This Festival Needs Ground Breaking Maintenance. Meftih, p. 11. Berhane, A. (2007, September). Festival 2007: An Event of Wisdom. Meftih, pp. 4-11.

Berhane, A. (2007, August). A Plot That Must Be Disclosed. Meftih, p. 15.

Berhane, A. (2007, August 1). Censored At Gunpoint. Retrieved September 7, 2015, from http://globaljournalist.jour.missouri.edu/content/emprint/2007_winter.pdf 
Berhane, A. (2010, January). E.C.A.O., A Community Looted By Its Guardian. Meftih, pp. 1-12.

Berhane, A. (2012). Writers in Exile: What Shuts Them Up? | Literary Review of Canada. Retrieved August 7, 2015, from http://reviewcanada.ca/magazine/2012/01/writers-inexile-what-shuts-them-up/

Bernal, V. (2006). Diaspora, cyberspace and political imagination: the Eritrean diaspora online. Global networks, 6(2), 161-179.

Bozzini, D. M. (2011). Low-tech surveillance and the despotic state in Eritrea. Surveillance \& Society, 9(1/2), 93-113.

Bruce, C., Grant, A., \& Reynolds, C. (2010). Out of the Fire and into the Pot: The Eritrean Liberation Movement, the Right to Self-Determination and the Over-Breadth of North American Immigration Security Provisions. Geo. Immigr. LJ, 25, 859.

Canada Gazette (2010). Regulations Implementing the United Nations Resolution on Eritrea. Retrieved July 2, 2015 from_http://canadagazette.gc.ca/rp-pr/p2/2010/2010-0512/html/sor-dors84-eng.html

Canada, Parliament. House of Commons. Subcommittee on International Human Rights of the Standing Committee on Foreign Affairs and International Development. (2012). Evidence. February 14. 41st Parliament, 1st Session. Retrieved from http://www.parl.gc.ca/HousePublications/Publication.aspx?DocId=5384811\&Language= E\&Mode $=1$

CIC (2015). Applying for a Permanent Resident Card (PR card) - Initial application, replacement or renewal (IMM 5445). Retrieved August 6, 2015 from http://www.cic.gc.ca/english/information/applications/guides/5445ETOC.asp\#5445E4 
Commission of Inquiry on Human Rights in Eritrea (2015). Statement by Mr. Mike Smith, Chair of the Commission of Inquiry on Human Rights in Eritrea at the 29th session of the Human Rights Council - See more at: Retrieved from http://www.ohchr.org/EN/NewsEvents/Pages/DisplayNews.aspx?NewsID=16183\&LangI D=E\#sthash.fAJJCGIX.dpufhttp://www.ohchr.org/EN/NewsEvents/Pages/DisplayNews.a spx?NewsID=16183\&LangID=E

Commission of Inquiry on Human Rights in Eritrea. (2015). Human Rights Council, 97. Retrieved October 05, 2015, from http://www.ohchr.org/Documents/HRBodies/HRCouncil/CoIEritrea/A_HRC_29_CRP1.pdf

Connell, D. (2005). Conversations with Eritrean political prisoners. The Red Sea Press.

Conrad, B., \& Hepner, T. R. (2005). Eritrea Abroad. Critical Perspectives on the Global Diaspora. Eritrean Studies Review, 4(2), 37-8

Creswell, J. W. (2013). Qualitative inquiry and research design: Choosing among five approaches (3rd Edition). London: Sage Publications.

Danso, R. (2002). From 'there’to 'here': An investigation of the initial settlement experiences of Ethiopian and Somali refugees in Toronto. GeoJournal, 56(1), 3-14.

De Waal, A. (1991). Evil days: Thirty years of war and famine in Ethiopia (Vol. 3169, No. 69). Human Rights Watch

Fenta, H., Hyman, I., \& Noh, S. (2004). Determinants of depression among Ethiopian immigrants and refugees in Toronto. The Journal of nervous and mental disease, 192(5), 363-372. 
Fessehatzion, T. (2005). Eritrea's remittance-based economy: conjectures and musings. Eritrean studies review, 4(2).

Gedab News.(2011, July 29). Eritrean Regime: 2\% Dues Neither Mandatory, Nor An 'Income’ Tax. Retrieved September 8, 2015, from http://awate.com/eritrean-regime-2-dues-neithermandatory-nor-an-income-tax/

Goldring, L. (2008, February). Migrant Political Participation and Development: Re-politicizing development and resocializing politics. In SSRC Migration and Development Conference. New York, NY: Social Science Research Council (Vol. 28).http://www.un.org/en/ga/search/view_doc.asp?symbol=A/RES/390(V)

Goldsmith, A. (2005). Police reform and the problem of trust. Theoretical criminology, 9(4), 443-470.

Hepner, T. R. (2003). Religion, nationalism, and transnational civil society in the Eritrean diaspora. Identities: Global Studies in Culture and Power, 10(3), 269-293.

Hepner, T. M. R. (2004). Eritrea and exile: Trans/nationalism in the Horn of Africa and the United States.

Hepner, T. R. (2005). Transnational Tegadelti: Eritreans for Liberation in North America and the EPLF (Eritrean People's Liberation Front). Eritrean Studies Review, 4(2).

Hepner, T.R. (2008). Transnational governance and the centralization of state power in Eritrea and exile. Ethnic and Racial Studies, 31(3), 476-502.

Hepner, T. (2009). Soldiers, martyrs, traitors, and exiles: Political conflict in Eritrea and the diaspora. Philadelphia: University of Pennsylvania Press.

Hiebert, D. (2011). Precarious Housing and Hidden Homelessness among Refugees Asylum Seekers and Immigrants in Montreal, Toronto and Vancouver. Retrieved November 17, 
2015, from

http://www.esdc.gc.ca/eng/communities/homelessness/research/kdp/immigrants/precario us.shtml

Human Rights Watch (2009). Eritrea: Repression Creating Human Rights Crisis. Retrieved August 12, 22015, from http://www.hrw.org/news/2009/04/16/eritrea-repression-creatinghuman-rights-crisis

Independent Advisory Group on Country Information. (2015, September 1). Country Information and Guidance Eritrea: Illegal Exit. Retrieved November 7, 2015, from https://www.gov.uk/government/uploads/system/uploads/attachment_data/file/459486/Eri trea_-_Illegal_Exit_-_v2_0e.pdf

Itzigsohn, J. (2000). Immigration and the boundaries of citizenship: the institutions of immigrants' political transnationalism. International Migration Review, 1126-1154.

Iyob, R. (1997). The Eritrean experiment: a cautious pragmatism?. The journal of modern African studies, 35(04), 647-673.

Joly, D. (1996). Haven or hell?: Asylum policies and refugees in Europe. Basingstoke, Hampshire: Macmillan Press.

Kibreab, G. (2007). The Eritrean Diaspora, the War of Independence, Post-Conflict (Re)construction and Democratisation. The Role of Diasporas in Peace, Democracy and Development in the Horn of Africa, 97.

Kibreab, G. (2009). Eritrea: a dream deferred. James Currey; Nordiska Afrikainstitutet,. Koser, K. (2003). New African diasporas. London: Routledge. 
Ku, J. (2011). Ethnic activism and multicultural politics in immigrant settlement in Toronto, Canada. Social Identities, 271-289.

La, J. (2004). Forced remittances in Canada's Tamil enclaves. Peace review, 16(3), 379-385.

Lam, L. (1996). From Being Uprooted to Surviving: Resettlement of Vietnamese-Chinese" Boat People. Montreal 1980-1990.

Levitt, P. (2009). Roots and routes: understanding the lives of the second generation transnationally. Journal of Ethnic and Migration Studies, 35(7), 1225-1242.

Lyons, T. \& Mandaville, P. (2012). Politics from afar: Transnational diasporas and networks. London: Hurst \&.

MacInnes-Rae, R. (2014). Eritrea collecting 'money for the dictator' from expats in Canada. http://www.cbc.ca/news/world/eritrea-collecting-money-for-the-dictator-from-expats-incanada-1.2680616.

Malterud, K. (2001). Qualitative research: standards, challenges, and guidelines. The lancet, 358(9280), 483-488.

MINISTRY OF FOREIGN AFFAIRS OF THE STATE OF ERITREA. (2011, October 17). Eritrea’s Response to the Report of the Somalia Eritrea Monitoring Group Report. Retrieved November 2, 2015, from http://www.aigaforum.com/articles/eritrea_text_of_response-un-somalia.pdf

Mishler, W. and R. Rose (1998) Trust in Untrustworthy Institutions: Culture and Institutional Performance in Post-communist Societies. Glasgow: Centre for the Study of Public Policy. 
Monitoring Group on Eritrea \& Somalia. (2012, September 22). Report of the Monitoring Group on Somalia and Eritrea pursuant to Security Council resolution 2002 (2011). Retrieved August 3, 2015, from http://www.securitycouncilreport.org/atf/cf/\%7B65BFCF9B-6D274E9C-8CD3-CF6E4FF96FF9\%7D/Somalia\%20S\%202012\%20545.pdf.

Newland, K., \& Patrick, E. (2004). Beyond remittances: the role of Diaspora in poverty reduction in their countries of origin, a scoping study by the Migration Policy Institute for the Department of International Development. Migration Policy Institute.

Poole, A. (2013). Ransoms, Remittances, and Refugees: The Gatekeeper State in Eritrea. Africa Today, 60(2), 66-82.

Popkin, E. (2003). Transnational migration and development in postwar peripheral states: an examination of Guatemalan and Salvadoran state linkages with their migrant populations in Los Angeles. Current Sociology, 51(3-4), 347-374.

Scallan, N. (2012). Eritrean government using consulate in Toronto to impose tax to bankroll military, UN charges. Retrieved August 1, 2015, from http://www.thestar.com/news/canada/2012/07/24/eritrean_government_using_consulate_i n_toronto_to_impose_tax_to_bankroll_military_un_charges.html

Stake, R. (1995). The art of case study research. Thousands Oaks, CA: Sage Publications Subcommittee on International Human Rights of the Standing Committee on Foreign Affairs and International Development. (2012, February 14). Retrieved November 20, 2015, from http://www.parl.gc.ca/HousePublications/Publication.aspx?DocId=5384811\&Language= E\&Mode $=1$ 
Tecle, S. (2012). The Paradoxes of State-led Transnationalism: Capturing Continuity, Change and Rupture in the Eritrean Transnational Social Field (Doctoral dissertation, YORK UNIVERSITY TORONTO).

Tecle, S., \& Goldring, L. (2013). From 'remittance’to 'tax': the shifting meanings and strategies of capture of the Eritrean transnational party-state. African and Black Diaspora: An International Journal, 6(2), 189-207.

Tewelde, N. (2009, January). A person who doesn't have truth burps after drinking water. Meseret, pp. 3-6.

Tezare, K., Said, T., Baheta, D., Tewolde, H. and Melles, A. (2006). The role of the Eritrean diaspora in peacebuilding and development: challenges and opportunities. Selam Peacebuilding Network, 2006.

Tronvoll, K. (1998). Mai Weini, a highland village in Eritrea: a study of the people, their livelihood, and land tenure during times of turbulence. The Red Sea Press.

UN Commission of Inquiry on Human Rights In Eritrea, (2015, June 05). Report of the detailed findings of the Commission of Inquiry on Human Rights in Eritrea. Retrieved November 26, 2015, from http://www.ohchr.org/Documents/HRBodies/HRCouncil/CoIEritrea/A_HRC_29_CRP1.pdf

UN Monitoring Group on Somalia \& Eritrea. (2011, July 18). Report of the Monitoring Group on Somalia and Eritrea pursuant to Security Council resolution 1916 (2010). (2011, July 18). Retrieved September 14, 2015, from http://reliefweb.int/sites/reliefweb.int/files/resources/Full_Report_1869.pdf 
UN Monitoring Group on Somalia and Eritrea (2012). Report of the Monitoring Group on Somalia and Eritrea pursuant to Security Council resolution 2002 (2011). Retrieved July 20, 2015, from http://www.un.org/ga/search/view_doc.asp?symbol=S/2012/545

UN Monitoring Group on Somalia \& Eritrea. (2015, September 22). Report of the Monitoring Group on Somalia and Eritrea pursuant to Security Council resolution 2182 (2014): Eritrea. Retrieved November 8, 2015, from http://www.securitycouncilreport.org/atf/cf/\{65BFCF9B-6D27-4E9C-8CD3CF6E4FF96FF9\}/s_2015_802.pdf UN

UNDP (2014). Human Development Report 2014. Retrieved November 8, 2015, from http://hdr.undp.org/sites/all/themes/hdr_theme/country-notes/ERI.pdf

UNHCR (2013). Report of the United Nations High Commissioner for Refugees. Retrieved September 2, 2015, from_http://www.unhcr.org/5244440f9.html

UNHCR (2014). Sharp increase in number of Eritrean refugees and asylum-seekers in Europe, Ethiopia and Sudan. Retrieved from http://www.unhcr.org/5465fea1381.html Weldehaimanot, S. M. (2011). When Nationals of Democracies Support Dictators: Legality of the Two Percent and the YPFDJ. Eritrean Law Society Occasional Papers, 9.

World Bank. (2014). World Development Indicators. Retrieved November 30, 2015, from http://data.worldbank.org/country/eritrea •

Yin, R. (2009). Case study research: Design and methods (4th ed.). Thousand Oaks, Calif.: Sage Publications. 